norden

Unga i arbete i Norden

Ungas väg mot etablering på arbetsmarknaden i de nordiska länderna 

U nordon 



\section{Unga i arbete i Norden}

Ungas väg mot etablering på arbetsmarknaden i de nordiska länderna

Åsa Olli Segendorf

TemaNord 2013:572 
Unga i arbete i Norden

Ungas väg mot etablering på arbetsmarknaden i de nordiska länderna

Åsa Olli Segendorf

ISBN 978-92-893-2625-4

http://dx.doi.org/10.6027/TN2013-572

TemaNord 2013:572

(C) Nordiska ministerrådet 2013

Layout: Hanne Lebech

Omslagsfoto: ImageSelect

Denna rapport är utgiven med finansiellt stöd från Nordiska ministerrådet. Innehållet i rapporten avspeglar inte nödvändigtvis Nordiska ministerrådets synpunkter, åsikter eller rekommendationer.

www.norden.org/sv/publikationer

\section{Det nordiska samarbetet}

Det nordiska samarbetet är ett av världens mest omfattande regionala samarbeten. Det omfattar Danmark, Finland, Island, Norge och Sverige samt Färöarna, Grönland och Åland.

Det nordiska samarbetet är politiskt, ekonomiskt och kulturellt förankrat och är en viktig partner i europeiskt och internationellt samarbete. Den nordiska gemenskapen arbetar för ett starkt Norden i ett starkt Europa.

Det nordiska samarbetet ska stärka nordiska och regionala intressen och värderingar i en global omvärld. Gemensamma värderingar länderna emellan bidrar till att stärka Nordens ställning som en av världens mest innovativa och konkurrenskraftiga regioner.

\section{Nordiska ministerrådet}

Ved Stranden 18

DK-1061 København K

Telefon (+45) 33960200

www.norden.org 


\section{Innehåll}

Mot en fast förankring på arbetsmarknaden......................................................................

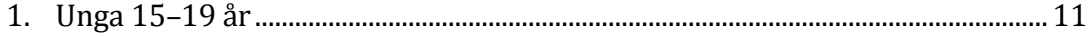

1.1 En samlad bild av utbildning och arbete för unga 15-19 år .................. 11

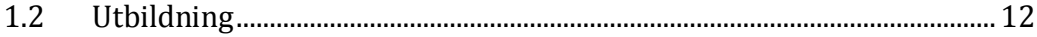

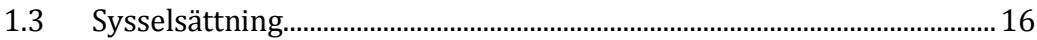

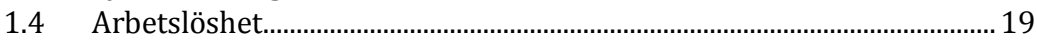

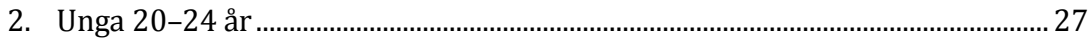

2.1 En samlad bild av utbildning och arbete för unga 20-24 år ................... 27

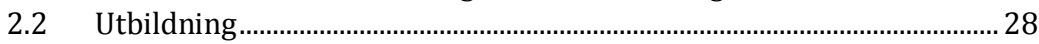

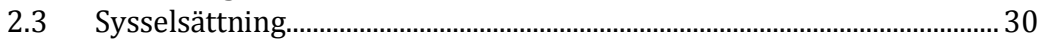

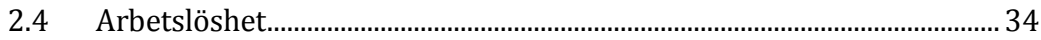

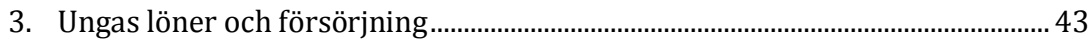

4. Unga vuxna 25-29 år......................................................................................... 49

4.1 En samlad bild av utbildning och arbete för unga vuxna 25-29 år ...... 49

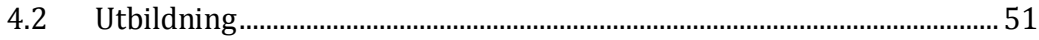

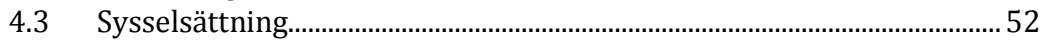

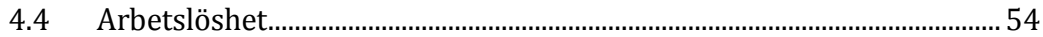

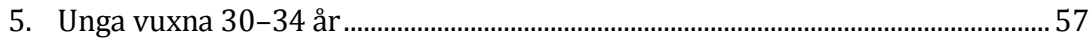

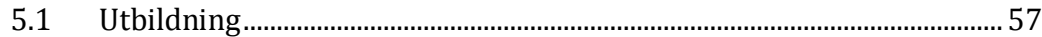

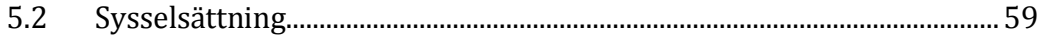

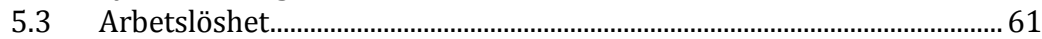

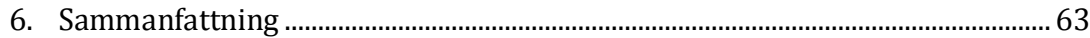

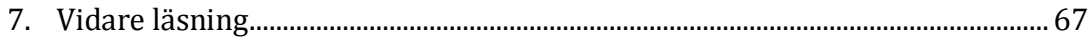

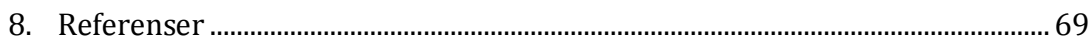

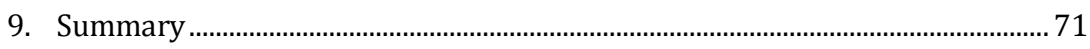

10. Bilaga 1: Arbetskraftsundersökningarna (AKU) ................................................... 75

11. Bilaga 2: Jämförbarhet i statistiken mellan de nordiska länderna.................... 79

12. Bilaga 3: Grund- och gymnasieskolans organisering i de nordiska

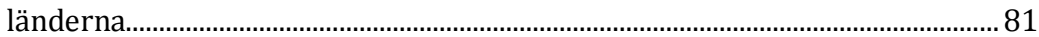

13. Bilaga 4: Lagstiftning kring tidsbegränsade anställningar ................................ 85 



\section{Mot en fast förankring på arbetsmarknaden $^{1}$}

Under det svenska ordförandeskapet i Nordiska ministerrådet år 2013 har Sverige fördjupat det nordiska regeringssamarbetet kring några av de stora framtidsutmaningar som är gemensamma för Norden. En viktig framtidsutmaning är att få fler unga i arbete. Även om de allra flesta unga till slut etablerar sig på arbetsmarknaden och får fast anställning pekar den höga ungdomsarbetslösheten på att ungas inträde på arbetsmarknaden kan bli snabbare och enklare. Ungdomsarbetslösheten är en utmaning för samtliga nordiska länder, men erfarenheterna och åtgärderna skiljer sig åt. Under ordförandeskapsåret har det därför skett ett brett kunskapsutbyte mellan de nordiska länderna om hur ungdomars inträde i arbetslivet kan underlättas.

En del i kunskapsutbytet om ungas arbetsmarknadssituation skedde under ett nordiskt arbetsmarknadsmöte den 16 maj 2013 i Stockholm. Vid mötet utbytte bl.a. de nordiska stats- och arbetsmarknadsministrarna erfarenheter och diskuterade ungdomars situation på arbetsmarknaden. Inför erfarenhetsutbytet på mötet togs ett statistiskt jämförande översiktsunderlag över ungas situation på arbetsmarkanden i de nordiska länderna fram. Denna rapport bygger på det bakgrundsmaterialet och $\mathrm{i}$ rapporten redovisas figurerna och tabeller. Bifogat denna publikation ligger den underliggande statistiken till figurerna på Nordiska ministerrådets hemsida (www.norden.org). ${ }^{2}$

\footnotetext{
${ }^{1}$ Ett stort tack riktas till de två referensgrupper bestående av forskare och statistiker i de nordiska länderna som bistått arbetet och hjälpt till med kvalitetssäkring av statistiken.

2 Den underliggande statistiken till figurerna som redovisas i denna rapport samt ytterligare variabler som samlades in inför detta kunskapsunderlag.
} 
De nordiska länderna har mycket gemensamt i etableringsprocessen för unga, bl.a. är det många som studerar, långtidsarbetslösheten är låg $\mathrm{i}$ en internationell jämförelse och sysselsättningsgraden bland unga vuxna (25-34 år) är högre än i många andra OECD-länder. Gemensamt är också att det bl.a. är unga med kort eller oavslutat gymnasieutbildning eller de som är utrikes födda som har det betydligt svårare att etablera sig på arbetsmarknaden. I sammanfattningen redovisas de huvudsakliga mönstren som kan urskiljas i och mellan länderna.

Det finns faktorer som försvårar direkta jämförelser mellan länder. Ett exempel är systemen med lärlingar. Under praktiken blir lärlingen som får lön klassad som sysselsatt och det ökar sysselsättningsgraden i de länder som har en hög andel lärlingar. Den offentliga diskussionen kompliceras också av att statistiken har olika beräkningsgrunder - t.ex. är arbetslöshetstalet en kvot mellan antalet arbetslösa och antalet personer i arbetskraften till skillnad från sysselsättningen som relaterar till hela befolkningen. ${ }^{3}$

\footnotetext{
${ }^{3}$ Arbetslöshetsmåttet i AKU är inte avhängigt av om personen är registrerad vid den nationella arbetsförmedlingen eller inte, och de påverkas inte heller av deltagande i arbetsmarknadspolitiska program (annat än subventionerad sysselsättning) på annat vis än om detta har effekter på sökbeteende eller övergångar till jobb.
} 


\section{Disposition}

Underlaget är disponerat enligt följande bild av etableringsprocessen:

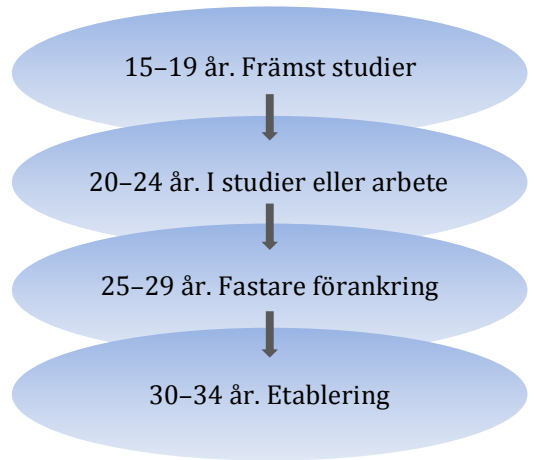

För respektive åldersgrupp beskriver rapporten övergripande unga i utbildning och på arbetsmarknaden. Den första åldersgruppen, 15-19 år är en grupp unga som i huvudsak utbildar sig på gymnasiet. Unga i åldersgruppen 20-24 år har i många fall lämnat gymnasiet, och börjat etablera sig på arbetsmarknaden eller gått vidare till högre studier. Gruppen 25-29 år har en fastare förankring på arbetsmarknaden än de yngre åldersgrupperna, men en relativt hög andel studerar fortfarande i alla nordiska länder. De ytterligare något äldre, unga vuxna 30-34 år är fastare etablerade på arbetsmarknaden och har i de flesta fall hunnit avsluta sina studier. Figurerna redovisar genomsnitt för de olika åldersgrupperna. I de fall ett land har förändrat t.ex. sitt utbildningssystem under tidigare år kan det tidigare systemet ha haft påverkan enbart på de äldre åldersgrupperna.

Eftersom unga befinner sig i olika faser i etableringsprocessen kompletteras de centrala måtten med viss specifik information om respektive åldersgrupp. Några få viktiga mått, t.ex. arbetslöshet för de som inte fullföljt gymnasiet, går inte att redovisa med ovanstående åldersgruppsindelning. Det har därför för fullständighetens skull varit nödvändigt att även redovisa vissa mått för ålderskategorierna 15-24 år, 18-24 år och 25-54 år.

Avslutningsvis refereras till litteratur där ungdomars situation i de Nordiska länderna diskuteras vidare och som beskriver politik som förs för att motverka ungdomsarbetslöshet i de olika nordiska länderna. 
Några centrala definitioner i korthet:

- Ungdomar beskrivs vanligen med ålderskategorin 15-24 år. Det är dock stora skillnader i etableringsgrad på arbetsmarknaden inom den relativt breda ålderskategorin så här är unga uppdelade i ålderskategorin 15-19 år och 20-24 år.

- En person studerar om han eller hon är inskriven på en utbildning under referensperioden. Studerandegraden är andelen unga i befolkningen som studerar.

- En person är sysselsatt om han eller hon arbetar under minst en timme under en vecka, är tillfälligt frånvarande från arbetet när intervjuaren kontaktar personen eller deltar i en aktivitet där lön utbetalas från arbetsgivaren (t.ex. ett arbetsmarknadspolitiskt program eller en lärlingsutbildning). Sysselsättningsgraden är andelen unga i befolkningen som är sysselsatta.

- En person är arbetslös om han eller hon deltar i arbetskraften och är utan arbete under referensperioden. Arbetslöshet är andelen unga i arbetskraften som inte är sysselsatta och söker arbete. Notera att Figur 1, Figur 13 och Figur 28 avviker från de av International Labour Organizations (ILO) internationellt vedertagna definitionerna och beräknar arbetslösheten i relation till hela befolkningen i åldersgruppen.

- Med att vara etablerad menas i den här rapporten att vara sysselsatt. 


\section{Unga 15-19 år}

\subsection{En samlad bild av utbildning och arbete för unga 15-19 år}

Figur 1 redovisas ungas huvudsakliga aktivitet i utbildningssystemet och på arbetsmarknaden. Unga i åldersgruppen studerar i huvudsak. Näst vanligast i de flesta länder är att vara sysselsatt. Därutöver är det en mindre andel som är arbetslösa eller inaktiva. Notera att arbetslösheten i figuren skiljer sig från den officiella definitionen enligt International Labour Organizations (ILO) på arbetslöshet dels genom att de arbetslösa som samtidigt studerar räknats bort och dels genom att antalet arbetslösa relateras till befolkningen i stället för till arbetskraften. Båda dessa faktorer sänker arbetslöshetsnivån jämfört bl.a. med Figur 6 som beskriver arbetslösheten och som bygger på ILO:s definitioner.

Figur 1: Vad unga 15-19 år huvudsakligen gör, 15-19 år, 2010

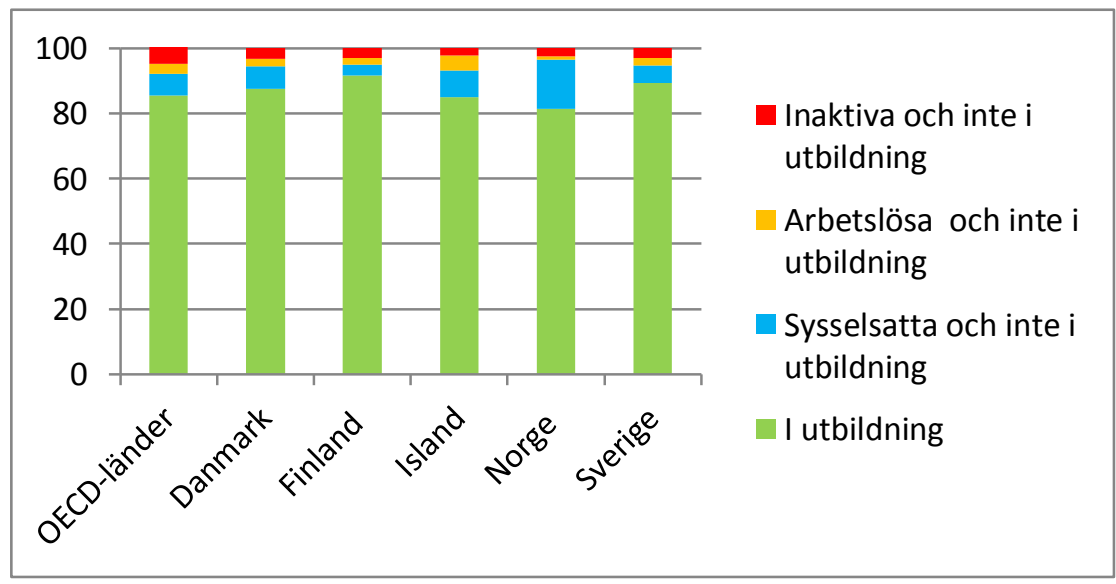

Anm.: Andelen av alla unga i åldersgruppen. Procent.

Källa: Data är sammansatt från from Network on Outcomes of Learning (LSO) nätverkets särskilda datainsamling, Adult Learning Working Group, OECD. 


\subsection{Utbildning}

I samtliga nordiska länder så är gymnasieutbildningarna väl utbyggda. Trots den höga studerandegraden i de nordiska länderna så finns det stora skillnader i hur gymnasieskolan är organiserad. Det beskrivs utförligt i bilaga 3. I Figur 2 redovisas studerandegraden bland unga 15-19 år i Norden. Den är markant högre för de nordiska länderna än för genomsnittet av alla OECD-länderna.

\section{Figur 2: Studerandegrad, totalt (a) och efter kön (b)}

Figur 2a: Studerandegrad, totalt, 15-19 år

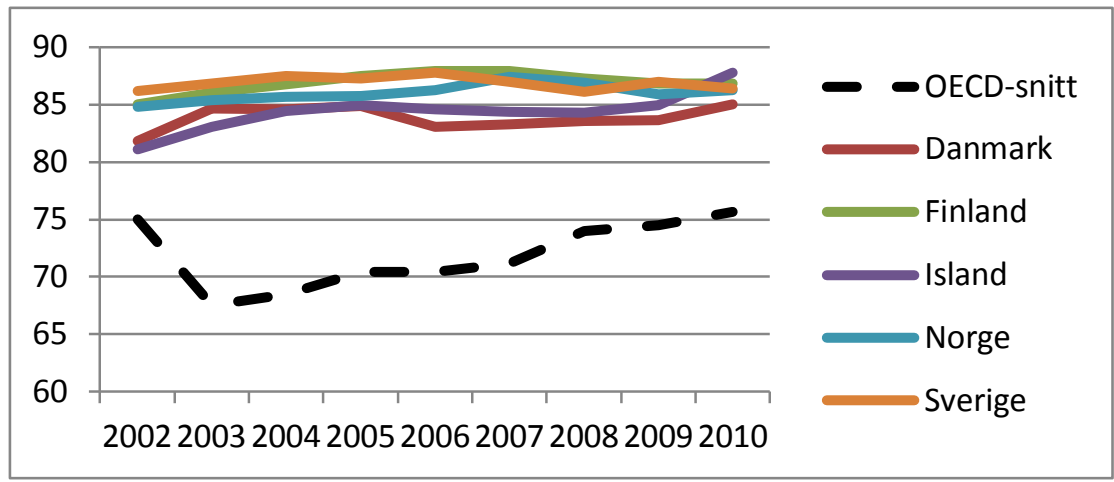

Anm.: Andelen studerande i åldersgruppen. Procent. Notera att skalan går mellan 60 och 90 procent.

Källa: UNESCO-OECD-Eurostat (UOE) datainsamling i kombination med registerbaserad administrativ statistik, OECD:s databaser samt egen bearbetning.

Det är i stort sett lika många flickor som pojkar som studerar (se Figur 2b). Fler pojkar väljer yrkesinriktade gymnasieutbildningar, medan flickorna i högre grad väljer studieförberedande gymnasieutbildning. 
Figur 2b: Studerandegrad för flickor och pojkar, 15-19 år, 2010

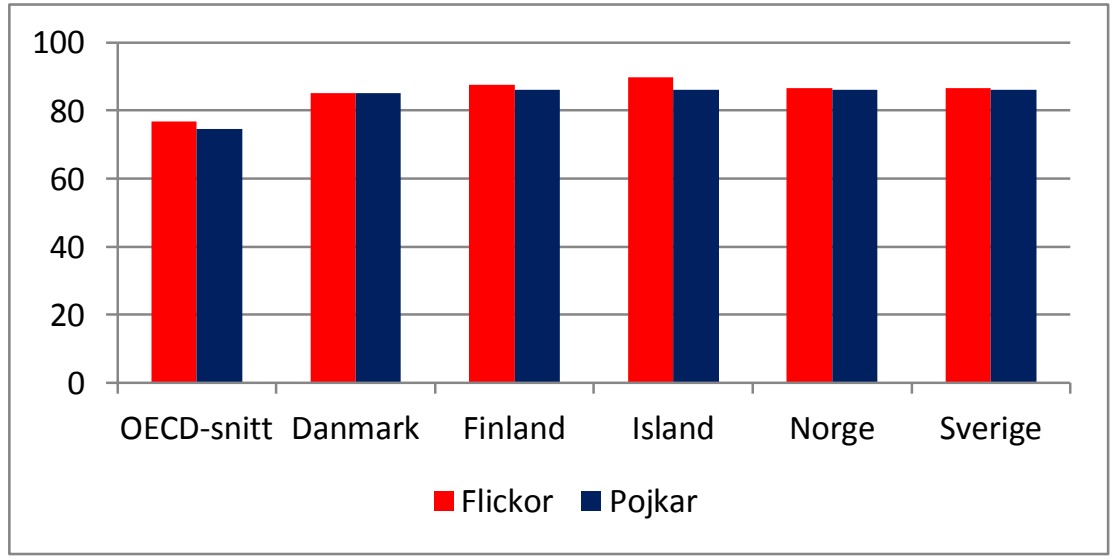

Anm.: Andelen studerande i åldersgruppen. Procent.

Källa: UNESCO-OECD-Eurostat (UOE) datainsamling i kombination med registerbaserad administrativ statistik, OECD:s databaser.

Den höga fullföljandegraden i Finland och Sverige som ses i Figur 3 beror delvis på att fler läser studieförberedande utbildningar i de nämnda länderna. Fullföljandegraden är oftast högre på studieförberedande utbildningar. Figur 3a visar den totala andelen av en kohort som påbörjade gymnasiet i mitten av 2000-talet och som fullföljt utbildningen inom normerad tid (ofta runt tre år) plus ytterligare två år totalt. Uppföljningen skedde först två år efter den normerade tiden för att tillåta korta avbrott $i$ utbildningen eller för att byta gymnasieskola eller inriktning på utbildningen utan att eleven ska räknas som att inte ha fullföljt utbildningen. Figur $3 \mathrm{~b}$ visar samma information men uppdelat på studieförberedande- och yrkesförberedande gymnasium. Tabell 1 visar fullföljandegraden uppdelat på kön.

Den höga fullföljandegraden för genomsnittet av OECD-länderna kan delvis bero på att det är en lägre andel som studerar (se Figur 2) och att de som studerar då i genomsnitt också har bättre förutsättningar att fullfölja en utbildning. En möjlig förklaring till den relativt låga fullföljandegraden på Island kan vara att arbetskraftsefterfrågan där har varit stark både för personer med och utan gymnasieutbildning samt att gymnasieutbildningar där i genomsnitt varar längre tid. 


\section{Figur 3: Fullföljandegrad, gymnasium totalt (a) samt efter inriktning (b)}

Figur 3a: Fullföljandegrad, gymnasium totalt

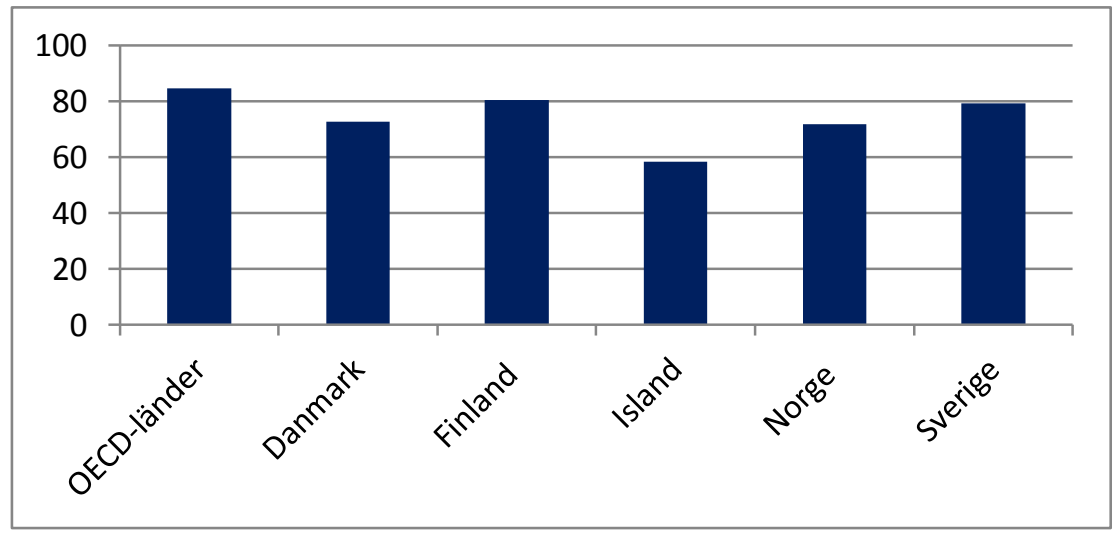

Anm.: Andelen av en kohort som påbörjade gymnasiet i mitten av 2000-talet och som fullföljt inom normerad tid plus två år. Procent.

Källa: Education at a Glance 2012, OECD. ${ }^{4}$

På yrkesutbildningarna i Sverige och Finland gör eleverna praktik och utbildningen är i huvudsak skolplatsförlagd, medan Danmark, Island och Norge huvudsakligen har ett system av lärlingar där utbildningen är arbetsplatsförlagd och ungdomarna får lön.

\footnotetext{
${ }^{4}$ Uppgifterna bygger på International Standard Classification of Education (ISCED). ISCED omfattar en skala med sex nivåer, från förskolenivå (nivå 0) till forskarutbildningsnivå (nivå 6) med en kategorisering av inriktningar under respektive nivå. En fullgjord gymnasieutbildning motsvarar nivå 3. Den delas i sin tur upp i 3A som motsvarar allmänt inriktad gymnasieutbildning och 3B som motsvarar yrkesinriktad gymnasieutbildning. Uppgifterna ska tolkas med försiktighet av främst två skäl. För det första är det inte självklart att det som klassificeras som nivå 3 i ISCED faktiskt är jämförbart mellan olika länder. Det kan vara allt från korta påbyggnadskurser efter grundskolan till längre utbildningar. Det andra skälet är att kraven för att anses ha fullgjort en utbildning kan skilja sig mellan länder. För vissa utbildningar gäller regelrätta examensprov medan det för andra räcker med ett aktivt deltagande för att räknas som godkänd.
} 
Figur 3b: Fullföljandegrad för studie-respektive yrkesförberedande gymnasium, År 2010

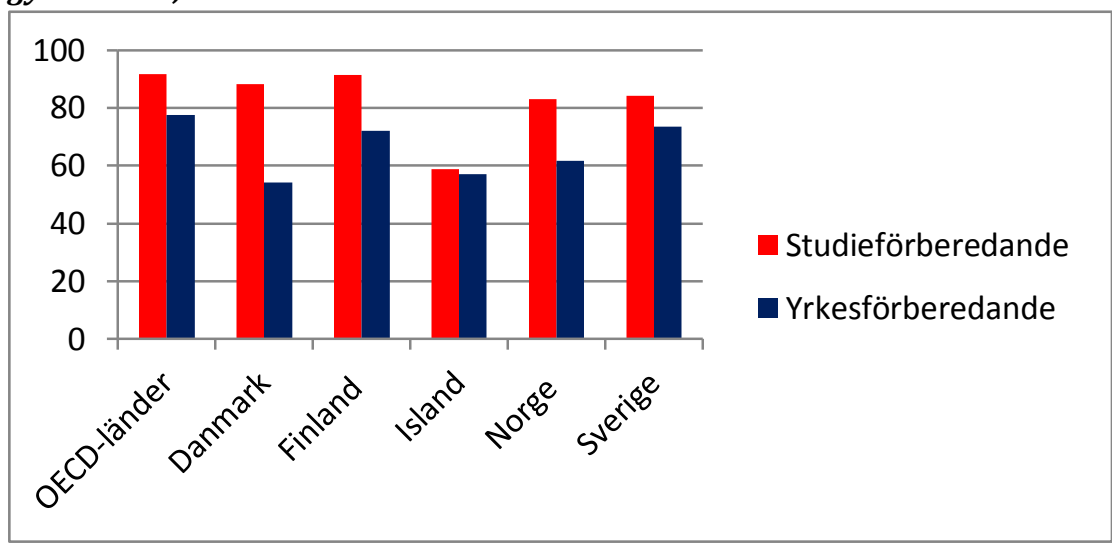

Anm.: Andelen av en kohort som påbörjade gymnasiet i mitten av 2000-talet och som fullföljt inom normerad tid plus två år. Procent.

Källa: Education at a Glance 2012, OECD.

Många fullföljer en gymnasieutbildning senare i livet genom sk. "second chance". Tabell 1 redogör både för andelen som uppnått minst fullföljt gymnasium som efter normerad tid plus två år (jämför Figur 3, här uppdelat efter kön) och andelen av de unga vuxna 25-34 år som har som lägsta utbildning fullföljt gymnasium. Även om det är en högre andel män som fullföljer gymnasieutbildningen senare i livet jämfört med kvinnor så har männen ändå i genomsnitt en lägre fullföljandegrad i vuxen ålder.

Tabell 1: Andel som fullföljt gymnasiet samt andel med minst fullföljt gymnasium vid 25-34 år

\begin{tabular}{|c|c|c|c|c|}
\hline & \multicolumn{2}{|c|}{$\begin{array}{l}\text { Andel som fullföljt gymnasiet inom } \\
\text { normerad tid plus två år }\end{array}$} & \multicolumn{2}{|c|}{$\begin{array}{l}\text { Andel som har uppnått minst gymnasie- } \\
\text { utbildning vid 25-34 års ålder }\end{array}$} \\
\hline & Flickor & Pojkar & Kvinnor & Män \\
\hline Danmark & 75,7 & 69,4 & 83,1 & 76,6 \\
\hline Finland & 82,6 & 78,0 & 92,8 & 88,9 \\
\hline Island & 65,2 & 51,4 & 76,7 & 68,1 \\
\hline Norge & 75,8 & 67,6 & 84,9 & 81,1 \\
\hline Sverige & 81,3 & 77,1 & 92,4 & 89,8 \\
\hline
\end{tabular}

Anm.: Andel av befolkningen som minst har fullföljt gymnasium samt andel med minst fullföljt gymnasium vid 25-34 års ålder. Procent.

Källa: OECD. 


\subsection{Sysselsättning}

Sysselsättningsgraden skiljer sig mer åt mellan de nordiska länderna för unga 15-19 år jämfört med de äldre åldersgrupperna. Till viss del beror den högre sysselsättnings i Danmark, Island och Norge på att de har en hög andel lärlingar och lärlingar som får lön räknas som sysselsatta i statistiken (se Tabell 2). En bidragande förklaring till den höga sysselsättningsgraden på Island är, förutom lärlingssystemet, den traditionellt sett starka arbetskraftsefterfrågan. I Figur $4 \mathrm{~b}$ ser vi att flickor generellt sett har något högre sysselsättningsgrad än pojkar.

\section{Figur 4: Sysselsättningsgrad, totalt (a) och efter kön (b)}

Figur 4a: Sysselsättningsgrad, totalt, 15-19 år

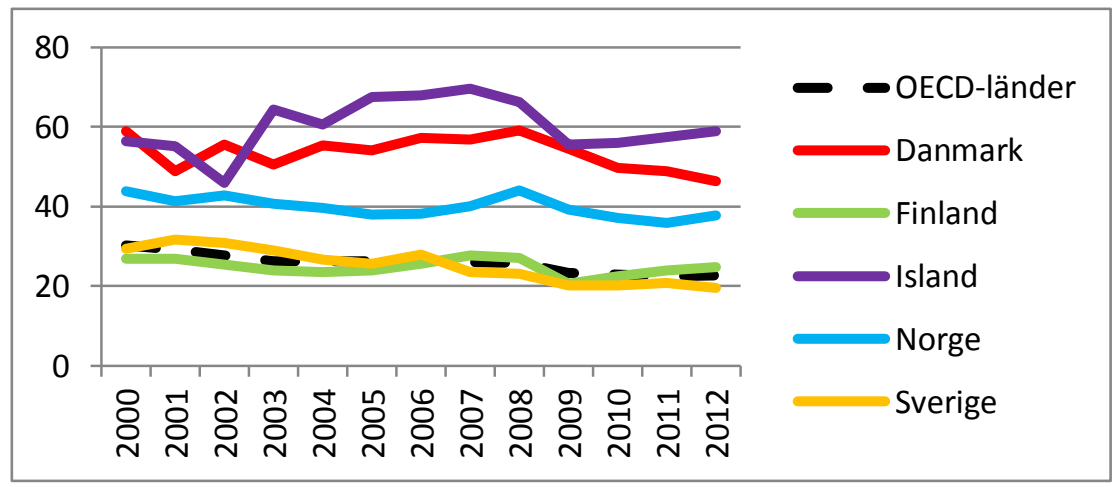

Anm.: Andelen sysselsatta i befolkningen. Procent. Notera att skalan slutar vid 80 procent. Källa: AKU, OECD. 
Figur 4b: Sysselsättningsgrad för flickor och pojkar, 15-19 år, 2012

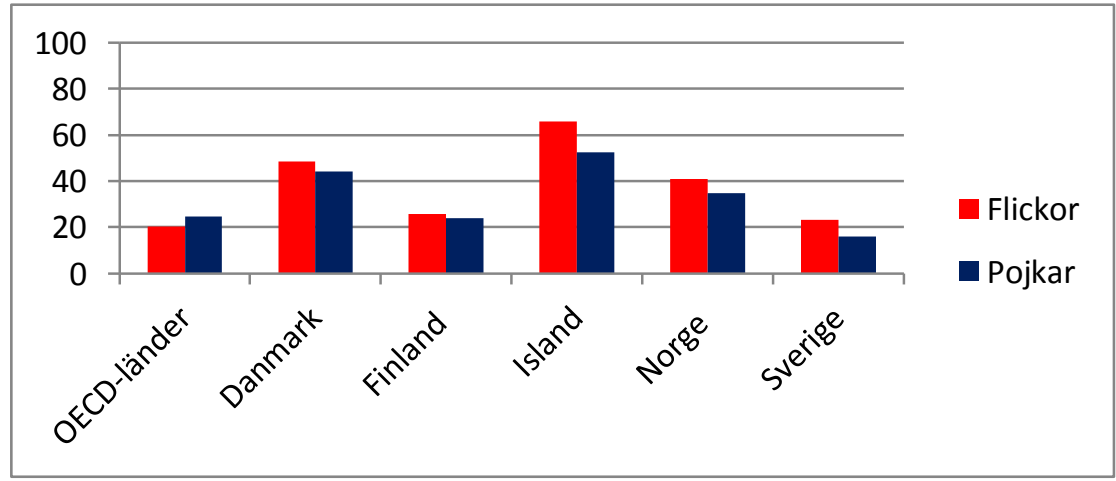

Anm.: Andelen sysselsatta i befolkningen. Procent.

Källa: AKU, OECD.

En majoritet av de sysselsatta unga i åldersgruppen arbetar deltid (se Figur 5: Deltidssysselsättning. Till viss del beror den höga andelen på att många unga arbetar vid sidan av studierna (se också diskussion om hur mycket ungdomar vill arbeta i de olika länderna, dvs. om de vill ha heltidseller deltidsarbete, i sysselsättningsavsnittet för åldersgruppen 20-24 år).

Figur 5: Deltidssysselsättning, 15-19 år

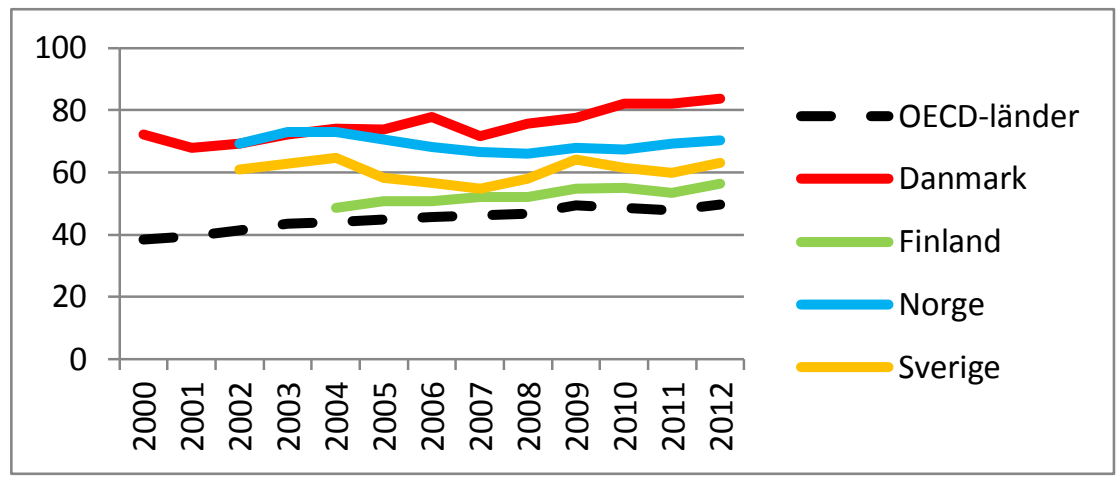

Anm.: Andelen av de anställda som arbetar deltid. Uppgifter saknas för Island. Procent. Källa: AKU, SCB och OECD. 


\section{Påverkan av lärlingssystemet på sysselsättningsstatistiken}

Alla de nordiska länderna följer ILO:s rekommendationer att lärlingar med lön ska klassificeras som sysselsatta i AKU (se Tabell 2). ${ }^{5}$

Av de sysselsatta unga i Danmark är nästan var fjärde lärling, som anges i sista kolumnen i Tabell 2. På Island och i Norge är det runt tio procent av de sysselsatta som är lärlingar. I Sverige är andelen försumbar. Sysselsättningsgraderna i samtliga länder förutom Sverige stiger därför till följd av hur lärlingssystemet är utformat. Det illustrerar också att skillnader i lärlingssystemens påverkan på statistiken inte förklarar hela skillnaden mellan länderna.

Tabell 2: Klassificering av lärlingsanställda i AKU, anställningskontrakt till lärlingar samt andelen gymnasielärlingar och den totala andelen lärlingar av alla studerande, 15-24 år, 2010

\begin{tabular}{|c|c|c|c|c|c|c|}
\hline & $\begin{array}{l}\text { Lärlingar } \\
\text { med lön } \\
\text { klassifice- } \\
\text { ras som } \\
\text { sysselsatta } \\
\text { i AKU }\end{array}$ & $\begin{array}{l}\text { Lärlingar är } \\
\text { anställda och } \\
\text { får lön }\end{array}$ & $\begin{array}{r}\text { Andel av } \\
\text { gymnasie- } \\
\text { studerande } \\
\text { som gick en } \\
\text { lärlingsutbild- } \\
\text { ning }\end{array}$ & $\begin{array}{r}\text { Andel av } \\
\text { det totala } \\
\text { antalet } \\
\text { studeran- } \\
\text { de som } \\
\text { var } \\
\text { lärlingar }\end{array}$ & $\begin{array}{r}\text { Andelen } \\
\text { lärlingar av } \\
\text { sysselsatta } \\
\text { studerande, } \\
\text { (2011) }\end{array}$ & $\begin{array}{r}\text { Andelen } \\
\text { lärlingar } \\
\text { av } \\
\text { syssel- } \\
\text { satta } \\
\text { totalt } \\
(2011)\end{array}$ \\
\hline Danmark & $\mathrm{Ja}$ & $\mathrm{Ja}$ & 40,5 & 20,6 & 36,4 & 23,9 \\
\hline Finland & $\mathrm{Ja}$ & $\mathrm{Ja}$ & 3,4 & 1,9 & 7,2 & 3,5 \\
\hline Island & $\mathrm{Ja}$ & Ja & Uppgift saknas & 8,2 & 17,7 & 10,4 \\
\hline Norge & $\mathrm{Ja}$ & Ja & 14,4 & 8,3 & 18,9 & 9,7 \\
\hline Sverige & $\mathrm{Ja}$ & $\begin{array}{l}\text { Frivilligt för } \\
\text { arbets-givaren }\end{array}$ & 0,9 & 0,5 & - & - \\
\hline
\end{tabular}

Anm.: Procent.

Källa: SCB 2013:1.

\footnotetext{
${ }^{5}$ Dessa siffror är specialframtagna av statistikbyråerna i respektive länder och är inte en del av ländernas officiella statistik. Därför bör siffrorna endast användas som ett riktmärke för andelen lärlingar. Ländernas utgångspunkt har varit det underlag som användes till OECD:s rapport Education at a Glance 2012 i en tabell över studerande i yrkesutbildningar med mer än 25 procent av studietiden arbetsplatsförlagd. Underlaget har kvalificerats ytterligare och indelats i ålderskategorier. SCB har därefter jämfört de insamlade siffrorna med uppskattningen av antalet lärlingar enligt Tabell 2. De två källorna ger en relativt samstämmig bild av andelen lärlingar i länderna. För att beräkna sysselsatta 2011 så har siffrorna från 2010 applicerats på AKU-siffror för 2011. Eftersom de flesta lärlingar i Sverige inte får lön så kvalificeras de inte som sysselsatta i AKU.
} 


\subsection{Arbetslöshet}

Danmark, Island och Norge har låg arbetslöshet i förhållande till övriga nordiska länder och det internationella genomsnittet (se Figur 6). Till viss del kan detta mönster förklaras av att lärlingar registreras som sysselsatta i statistiken eftersom lärlingen som klassificerats som sysselsatt inte samtidigt klassificeras som arbetslös, även om han eller hon söker extraarbete på helger, lov eller liknande. Finland och Sverige har skolförlagda yrkesutbildningar och får inte lön under praktiken och de elever som söker extraarbete räknas då som arbetslösa i statistiken. Unga har dock en hög arbetslöshet i relation till äldre i samtliga nordiska länder (se Figur 19).

Uppdelat på kön så har flickor lägre arbetslöshet än pojkar förutom i Finland, se Figur 6. Arbetslösheten bland ungdomar har ökat kraftigt sedan hösten 2008. Erfarenheten visar att då konjunkturen viker så drabbas ungdomar först, vilket bland annat beror på att många ungdomar har tidsbegränsade anställningar (se Figur 18).

\section{Figur 6: Arbetslöshet, totalt (a) och efter kön (b)}

Figur 6a: Arbetslöshet, totalt, 15-19 år

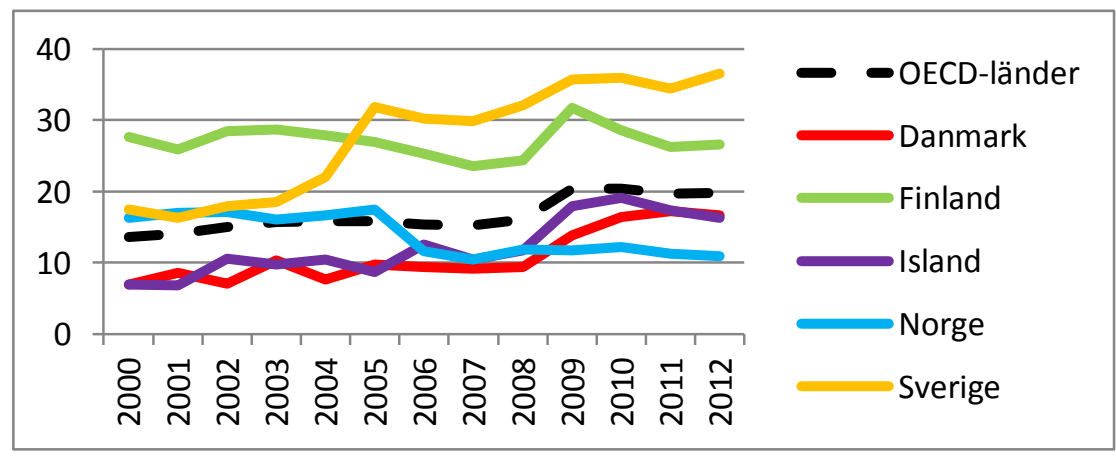

Anm.: Andelen arbetslösa av arbetskraften. Procent. Notera att skalan endast går till 40 procent. Källa: AKU, OECD. 
Figur 6b: Arbetslöshet för flickor och pojkar, 15-19 år, 2012

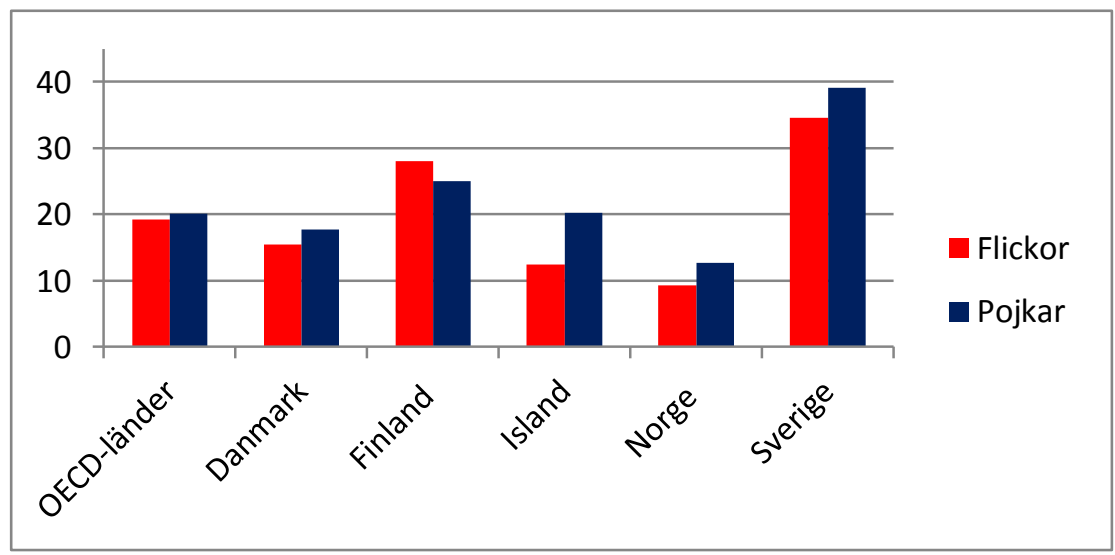

Anm.: Andelen arbetslösa av arbetskraften. Procent. Notera att skalan endast går till 40 procent. Källa: AKU, OECD.

Figur 7 visar andelen att av de arbetslösa som samtidigt studerar är runt hög; 70-80 procent. Det bekräftar mönstret i Figur 1.

Figur 7: Heltidsstuderande arbetslösa, 15-19 år, 2011

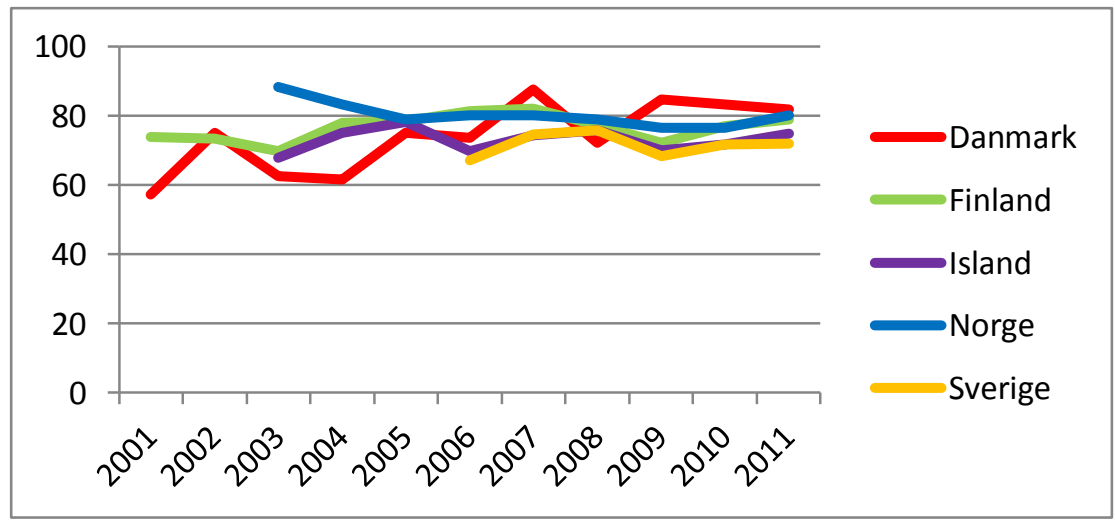

Anm.: Andelen heltidsstuderande av de arbetslösa. Enbart reguljära studier, arbetsmarknadspolitiska program ingår inte. Procent.

Källa: SCB. 
Eftersom en så betydande del av de unga arbetslösa är heltidsstuderande arbetslösa så sjunker arbetslösheten mycket när heltidsstuderande exkluderat (se Figur 8).

Figur 8: Arbetslöshet exklusive heltidsstuderande, 15-19 år

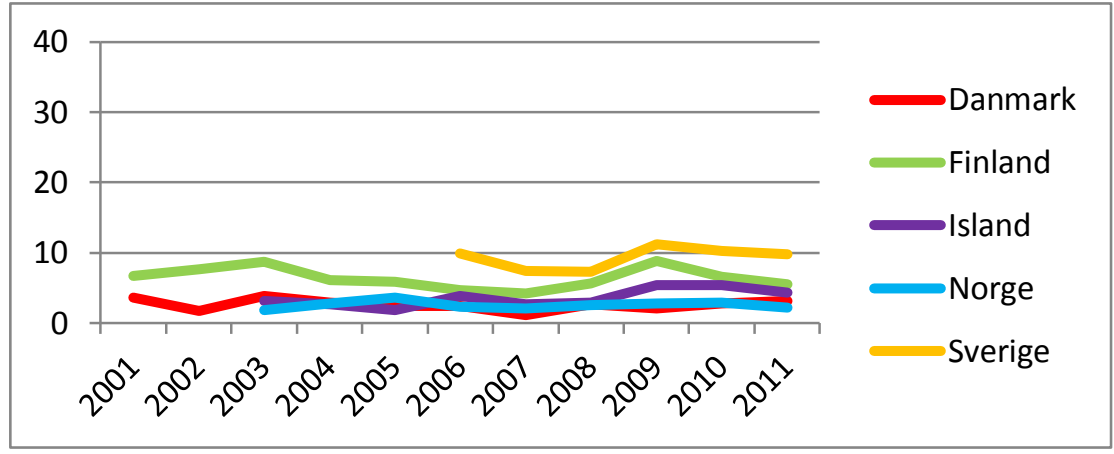

Anm.: Arbetslöshet exklusive reguljärt studerande. Notera att skalan slutar vid 40 procent. Källa: SCB och OECD, egna beräkningar.

Nivån på arbetslösheten under en viss period bestäms både av hur många som blir arbetslösa och hur lång tid personer är arbetslösa. Långa tider borta från arbetsmarknaden ger bestående svårigheter att anknyta eller återanknyta till arbetsmarknaden. Fördelningen av arbetslöshetstider uppvisar ett speciellt mönster för unga och är därför mycket intressant. Det är 30-40 procentenheter fler i gruppen 15-19 år som är arbetslösa högst tre månader jämfört med åldersgruppen 25-64 år i de nordiska länderna (Figur 9). Det tyder på att ungdomsarbetslösheten i stor utsträckning beror på att unga växlar mellan arbete och studier under skolåren. ${ }^{6}$

\footnotetext{
${ }^{6}$ I Sverige finns det tydliga skillnader i arbetslöshetstidens längd mellan de arbetslösa ungdomar som bedriver heltidsstudier och övriga ungdomar. Gruppen heltidsstuderande kännetecknas av kortare arbetslöshetsperioder. En förklaring till att de heltidsstuderande är arbetslösa under kortare perioder kan vara att dessa inte är lika aktiva som arbetssökande och att arbetslöshetsperioderna bryts av perioder då de studerande mer fokuserar på sina studier.
} 
Figur 9: Arbetslöshetstid under tre månader, 15-19 år

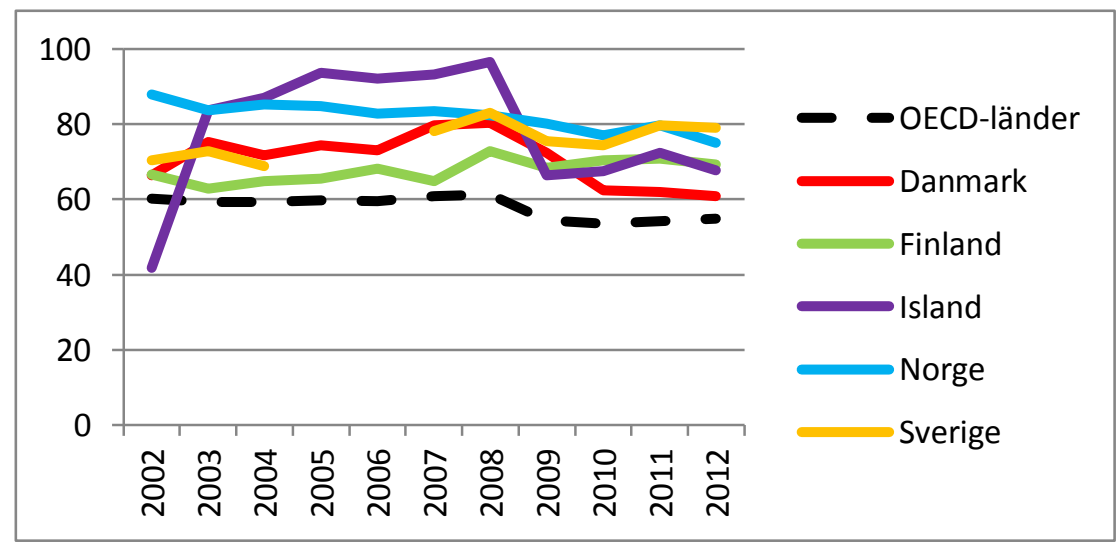

Anm.: Andelen av de arbetslösa som varit arbetslösa högst tre månader. Orsaken till tidsseriebrottet för Sveriges del var insamlingsproblem. Procent.

Källa: AKU, OECD.

Andelen korta arbetslöshetstider är hög. Det innebär att andelen långtidsarbetslösa i den här åldersgruppen är låg även om den totala arbetslöshetsnivån är hög, som illustreras i Figur 10. Långtidsarbetslösheten ökade efter den globala ekonomiska krisen och har i ett flertal länder börjat minska igen. 
Figur 10: Långtidsarbetslöshet, totalt (a) och efter kön (b)

Figur 10a: Långtidsarbetslöshet totalt, 15-19 år

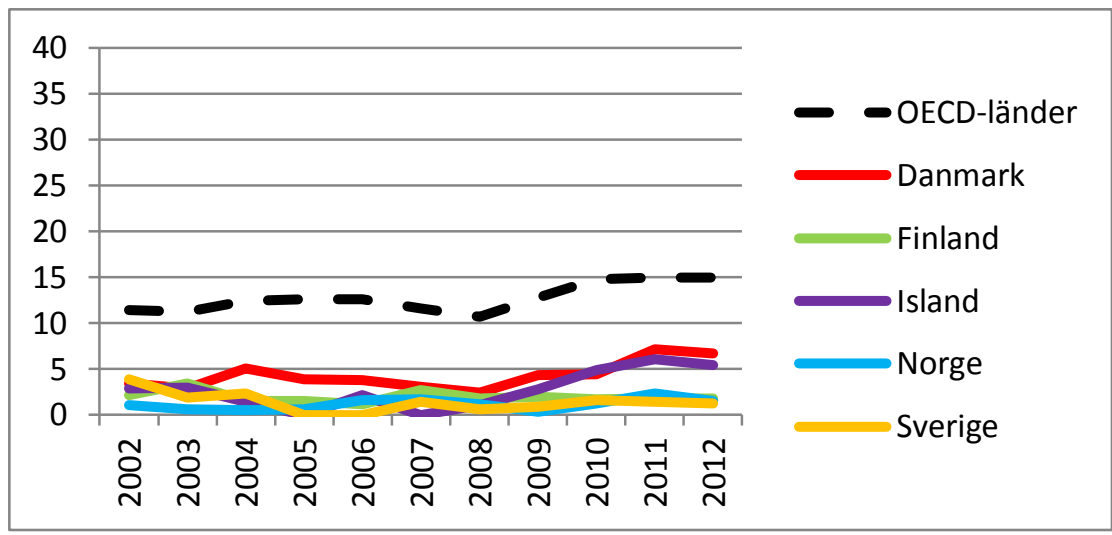

Anm.: Andelen arbetslösa som varit arbetslösa mer än ett år. Procent. Notera att skalan endast går till 40 procent. Källa: AKU, OECD.

Figur 10b: Långtidsarbetslöshet, efter kön, 15-19 år

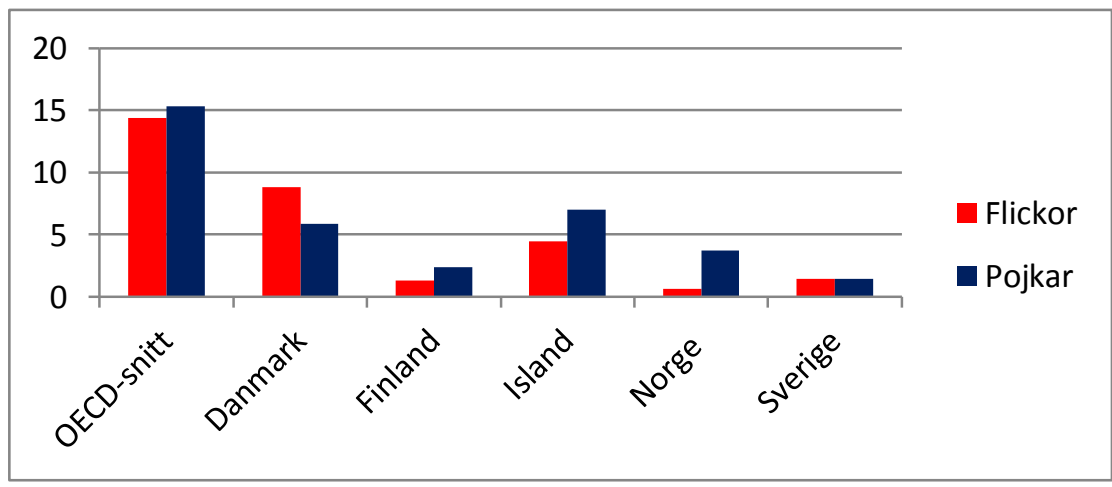

Anm.: Andelen arbetslösa som varit arbetslösa mer än ett år. Procent. Notera att skalan endast går till 20 procent.

Källa: AKU, OECD.

Även om det är en liten del som drabbas av långtidsarbetslöshet så har vissa grupper, t.ex. utrikes födda och de utan fullföljd gymnasieutbildning, större problem än andra. För utrikes födda kan problemen delvis hänga 
samman med att de har kommit i skolåldern, efter skolstart, och därför inte har hunnit få samma utbildning som sina jämnåriga skolkamrater. De har ett annat modersmål än det som talas i mottagarlandet vilket ger särskilda utmaningar i skolan. Delvis möter unga samma utmaningar med integration som övriga, vuxna, utrikes födda på arbetsmarknaden.

Andelen utrikes födda och sammansättningen av vilka länder de kommer ifrån av skiljer sig mycket mellan de olika nordiska länderna (se fördelningen för ensamkommande barn i Tabell 3). Andel utrikes födda är låg i Finland och på Island. Danmark, Norge och Sverige har högre andel utrikes födda men stora skillnader både i skälet att komma till landet och från vilket land de invandrade. Danmark och Norges största invandrargruppers invandringsskäl under de senare åren är att de är arbetskraftsinvandrare eller kom för studier, grupper som ofta klarar sig bättre på arbetsmarknaden än flykting och anhöriginvandring.

Figur 11: Arbetslöshet för inrikes och utrikes födda, 15-19 år, 2012

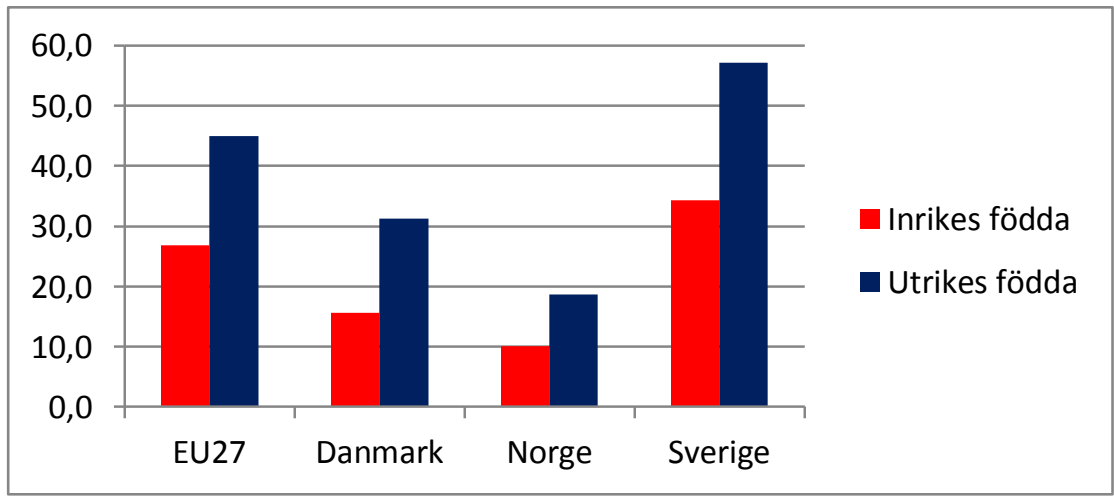

Anm.: Andel arbetslösa i arbetskraften. Uppgifter för utrikes födda saknas för Island och Finland. Procent.

Källa: AKU, Eurostat.

\section{Ensamkommande barn}

Sammansättning på de länder ensamkommande barn kommer ifrån skiljer sig mellan länderna, men de kommer främst från länder utanför Europa (se Tabell 3). Mer än två tredjedelar av de ensamkommande barnen som kommer till Danmark under tidsperioden kom från Afghanistan. I Finland var de största nationalitetsgrupperna somalier, irakier, afghaner och angolaner. 
Tabell 3: Ensamkommande barn i de nordiska länderna

\begin{tabular}{lrrrrr}
\hline & Danmark & Finland & Island & Norge & Sverige \\
\hline 2007 & - & - & - & 149 & 1264 \\
2008 & - & - & - & 207 & 1510 \\
2009 & 529 & - & - & 606 & 2250 \\
2010 & 432 & 329 & - & 669 & 2393 \\
2011 & 282 & 150 & - & 629 & 2657 \\
\hline
\end{tabular}

Källa: Referencemateriale till Det Nordiske Möte om Integration 2012.

\section{Not in education, employment or training - NEET}

Arbetslöshetsmåtten för unga inte oproblematiska att använda. Som nämnts är många unga studerande som söker extraarbete och de har också korta tider i arbetslöshet. Arbetslöshetsmåttet i AKU mäts relaterat till hur många unga som deltar i arbetskraften och inte relaterat till samtliga unga i åldersgruppen i fråga. Personer som deltar i lärlingsutbildning betraktas som sysselsatta eftersom de får lön under lärlingsutbildningen, och andelen lärlingar skiljer sig markant mellan länderna. Även de studenter som sökt och fått ett sommarjobb, och ska påbörja det inom tre månader, betraktas som arbetslösa under tiden.

Bland annat för att möta de ovanstående svårigheterna med att använda arbetslöshetsmåttet används NEET-måttet som ett komplement till arbetslöshetssiffran. NEET är en akronym för "not in education, employment or training". Måttet relateras till hela åldersgruppen. Andelen NEET 15-19 år var lägre i de nordiska länderna än i genomsnittet för EU27-länderna (se Figur 12). Kunskapen om denna grupp är mycket begränsad, men den kan utgöras av de grupper på arbetsmarknaden som upplever störst problem och som blir försörjda av sina föräldrar, unga som har annan okänd försörjning men också av unga som befinner sig utomlands. ${ }^{7}$

7 Till viss del motsvarar Figur 12 arbetslösa och inaktiva i, men det är olika datakällor varför det finns viss skillnad. 
Figur 12: Varken i utbildning eller i sysselsättning (NEET), 15-19 år, 2012

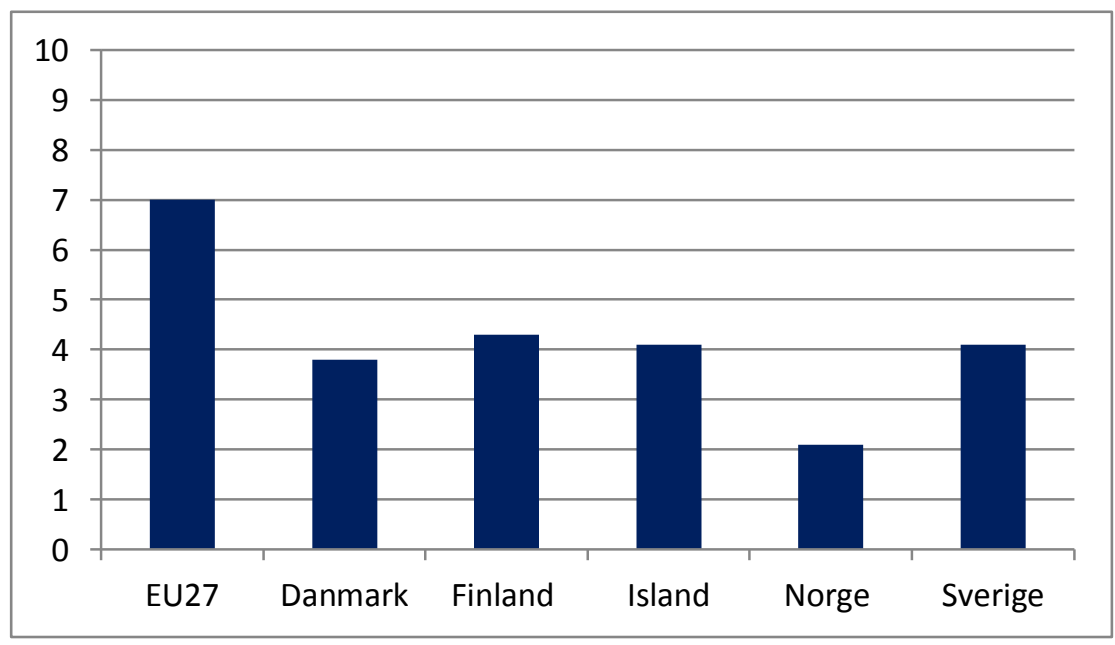

Anm.: Andelen av befolkningen som inte är i utbildning eller sysselsättning (NEET). Notera att skalan går till 10 procent.

Källa: Eurostat.

OECD har undersökt de grupper av unga som har svag anknytning till arbetsmarknad och utbildningssystemen. De finner att, förutom de som inte har fullföljt gymnasiet och utrikes födda, så har även unga med funktionshinder som medför nedsatt arbetsförmåga stora svårigheter. Även unga som har lågutbildade föräldrar, och/eller där föräldrarna är arbetslösa eller är beroende av försörjningsstöd för sin försörjning är i riskzonen. 


\section{Unga 20-24 år}

\subsection{En samlad bild av utbildning och arbete för unga 20-24 år}

I Figur 13 redovisas ungas huvudsakliga aktivitet i utbildningssystemet och på arbetsmarknaden. I jämförelse med den yngre åldersgruppen är det en lägre andel som studerar, och en högre andel som är sysselsatt. Andelen arbetslösa och inaktiva har också ökat. Notera att arbetslösheten i figuren skiljer sig från den officiella definitionen enligt International Labour Organizations (ILO) på arbetslöshet dels genom att de arbetslösa som samtidigt studerar räknats bort och dels genom att antalet arbetslösa relateras till befolkningen i stället för till arbetskraften. Båda dessa faktorer sänker arbetslöshetsnivån jämfört bl.a. med Figur 19 som beskriver arbetslösheten och som bygger på ILO:s definitioner.

Figur 13: Vad unga 20-24 år huvudsakligen gör, 20-24 år 2010

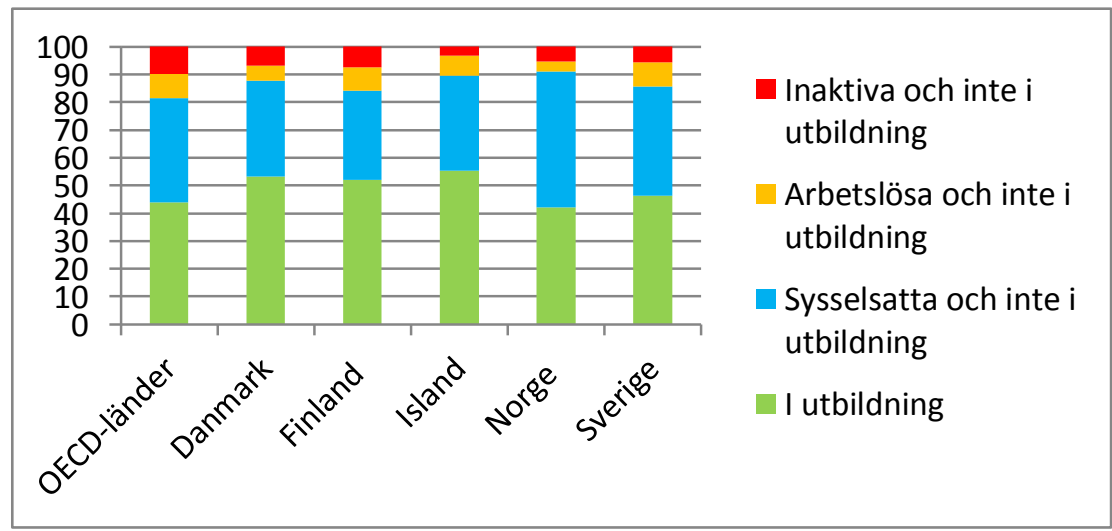

Anm.: Andelen av alla unga i åldersgruppen i en viss aktivitet. Procent.

Källa: Data är sammansatt från from Network on Outcomes of Learning (LSO) nätverkets särskilda datainsamling, Adult Learning Working Group, OECD. 


\subsection{Utbildning}

Studerandegraden för unga mellan 20-24 år är betydligt högre än genomsnittet för OECD (se Figur 14). Av Figur 14b framgår att fler kvinnor än män studerar i alla nordiska länder och att detta gäller också för hela OECD. Här visas enbart könsskillnaden för ett år för att illustrera könsskillnaden i varje land, men mönstret är detsamma för alla de studerade åren.

De nordiska länderna har ömsesidigt förpliktat sig att ge utbildningssökande som är bosatta i ett annat nordiskt land tillträde till sina offentliga högre utbildningar på samma eller likvärdiga villkor som sökande från det egna landet. En utbildningssökande, som är behörig till högre utbildning i det nordiska land, där han eller hon är bosatt, är också behörig till högre utbildning i de andra nordiska länderna. ${ }^{8}$

\footnotetext{
8 Med högre utbildning avses:

- Danmark: utbildningar vid institutioner för högre utbildning och högre utbildning vid andra utbildningsinstitutioner, som förutsätter gymnasieutbildning eller motsvarande kvalifikationer.

- Finland: utbildning vid universitet, högskolor och yrkeshögskolor, samt motsvarande utbildning som bygger på studentexamen eller annan utbildning som ger studiekompetens.

- Island: alla utbildningar som bygger på studentexamen eller likvärdiga kvalifikationer.

- Norge: utbildning vid universitet och högskolor eller motsvarande som bygger på genomförd och godkänd vidaregående upplärning eller motsvarande studiekompetensgivande utbildning.

- Sverige: utbildningar vid universitet och högskolor eller motsvarande som bygger på nationella program i gymnasieskolan eller motsvarande kvalifikationer och som omfattas av högskoleförordningen.

- Överenskommelsen gäller inte tillträde till forskarutbildning.
} 
Figur 14: Studerandegrad, totalt (a) och efter kön (b)

Figur 14a: Studerandegrad, totalt, 20-24 år

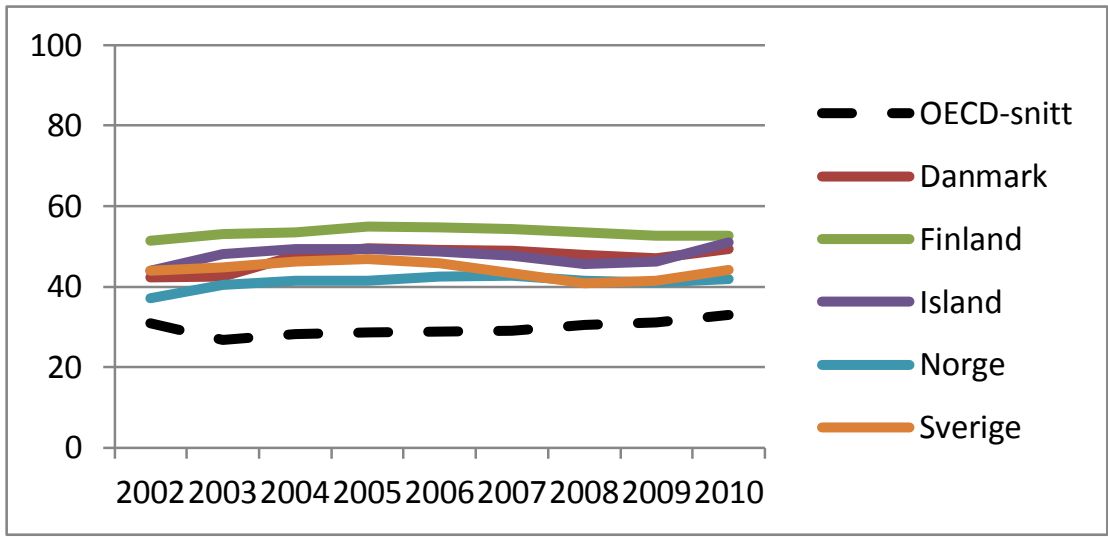

Anm.: Andelen studerande i åldersgruppen. Procent.

Källa: UNESCO-OECD-Eurostat (UOE) datainsamling i kombination med registerbaserad administrativ statistik, OECD:s databaser samt egen bearbetning.

Figur 14b: Studerandegrad för kvinnor och män, 20-24 år, 2010

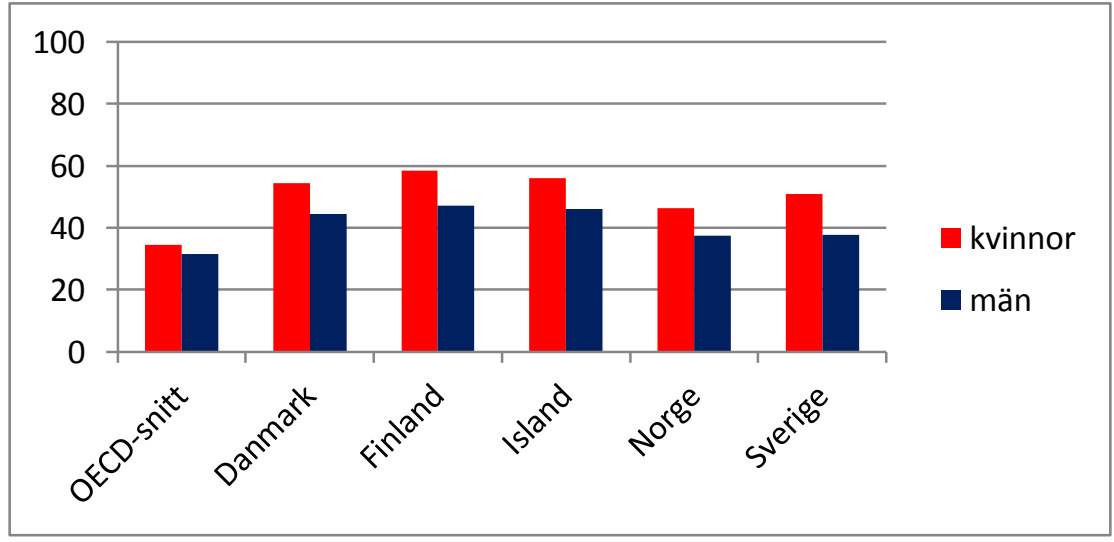

Anm.: Andelen kvinnor och män som studerar. Procent.

Källor: UNESCO-OECD-Eurostat (UOE) datainsamling i kombination med registerbaserad administrativ statistik, OECD:s databaser samt egen bearbetning. 
Det är en internationellt sett låg genomströmning på universitet och högskolor i de nordiska länderna, mätt i tid från när studenterna börjar på universitetet till dess de tar examen. Genomströmningen i utbildning var lägst i Sverige och Finland läsåret 2007/2008 (se Figur 15). Studenterna påbörjar sina studier sent. De nordiska länderna förutom Norge hade högre examensålder än det internationella genomsnittet. ${ }^{9}$

Figur 15: Genomströmning i eftergymnasial utbildning, Läsåret 2007/08

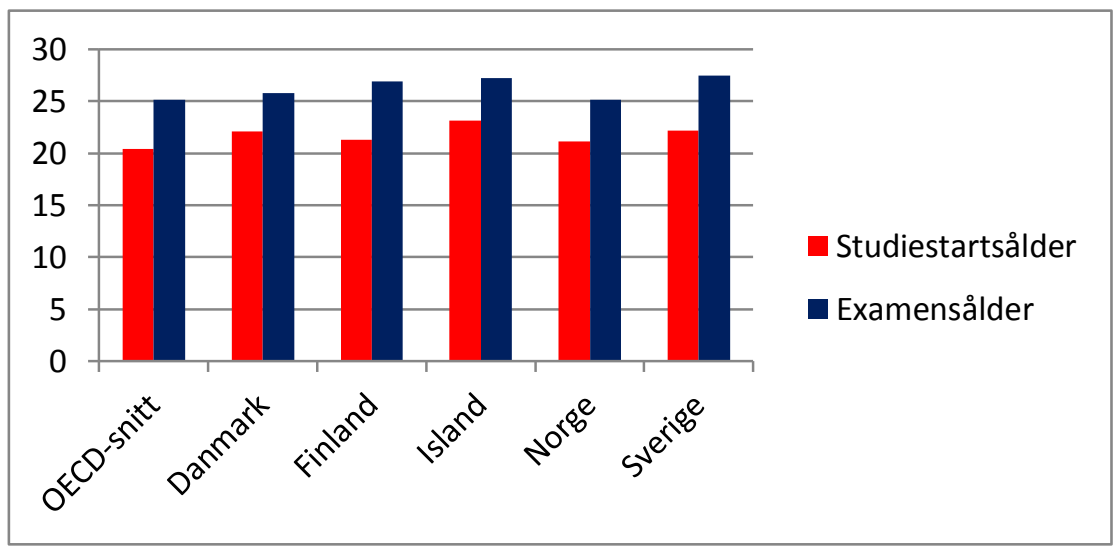

Anm.: Medianåldern bland samtliga nybörjare samt vid första examen på grundläggande nivå. Källa: OECD.

\subsection{Sysselsättning}

Mönstret för sysselsättningsgraden är likt det för den yngre åldersgruppen, men med mindre variation mellan länderna. Det finns fortfarande lärlingar i Danmark i den här åldersgruppen. Det är dock fortfarande skillnader i sysselsättningsgrad som inte förklaras av att lärlingar räknas som sysselsatta i statistiken.

En markant skillnad jämfört med den yngre åldersgruppen är att den senaste globala ekonomiska krisen tydligt syns i form av fallande syssel-

${ }^{9}$ Examensåldern sjunker när internationella studenter exkluderas från beräkningarna. 
sättningsgrader efter 2008. Det reflekterar att unga har en svagare anknytning till arbetsmarknaden generellt. Unga drabbas ofta relativt tidigt i en konjunkturnedgång jämfört med äldre personer. En orsak är att unga ofta har tidsbegränsade anställningar och därför lättare blir av med arbetet när företagen drar ner på personal (se Figur 18). Unga hämtar sig dock också snabbare i en konjunkturuppgång än vuxna. Sysselsättningen har i de flesta nordiska länderna börjat återhämta sig efter den globala krisen.

Figur 16: Sysselsättningsgrad, totalt (a) och efter kön (b)

Figur 16a: Sysselsättningsgrad, totalt, 20-24 år

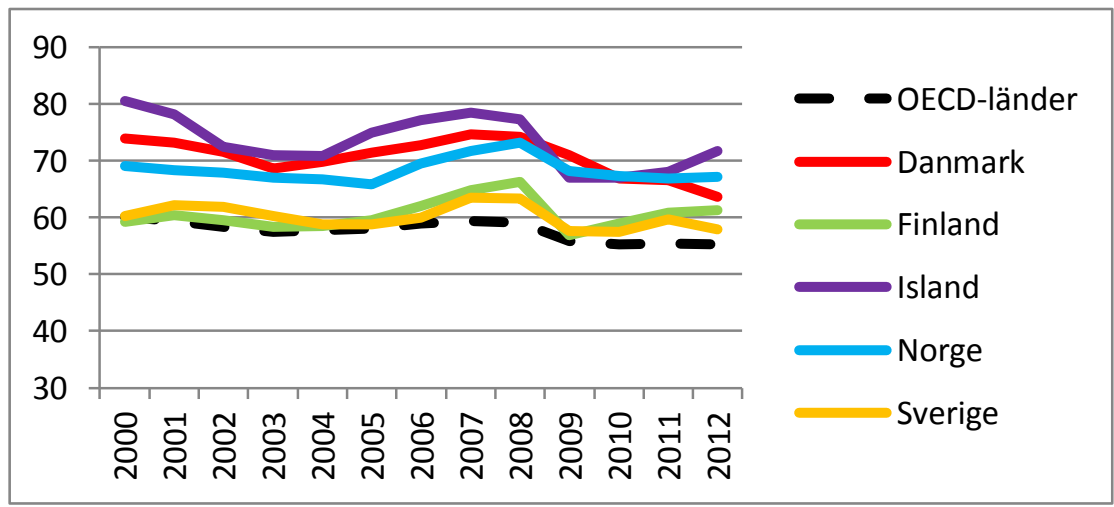

Anm.: Andelen sysselsatta i befolkningen. Procent. Notera att skalan börjar går mellan 30 och 90 procent.

Källa: AKU, OECD.

Till skillnad från studerandegraden, där fler kvinnor än män studerade, är det små skillnader mellan kvinnor och män i sysselsättningsgrad i åldersgruppen 20-24 år, se Figur 16b. I alla länder förutom Island är något fler män än kvinnor sysselsatta. Detta är också en skillnad jämfört med den yngre åldersgruppen, där flickor hade en högre sysselsättningsgrad än pojkar. 
Figur 16b: Sysselsättningsgrad för kvinnor och män, 20-24 år, 2012

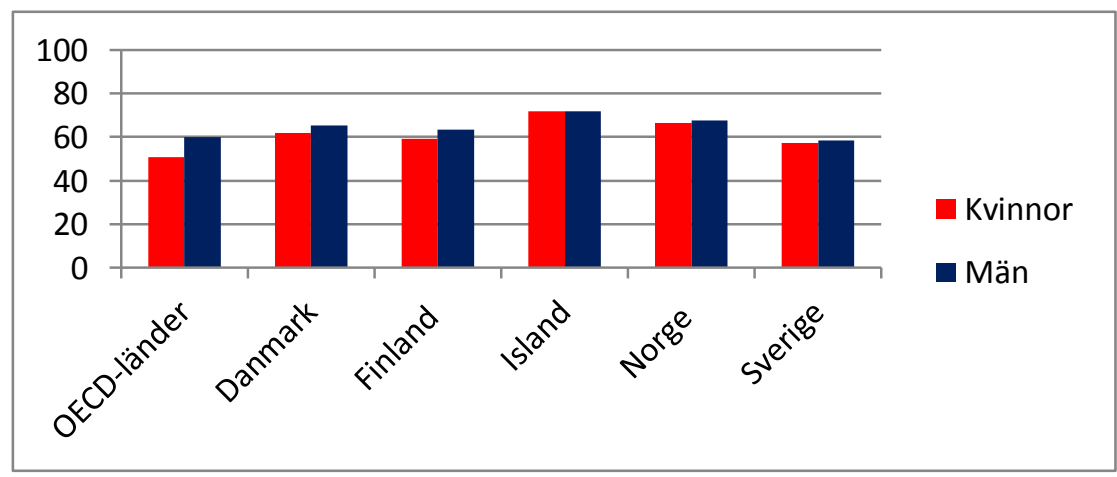

Anm.: Andelen sysselsatta i befolkningen. Procent.

Källa: AKU, OECD.

En hög sysselsättningsgrad bland unga kan tyda på att många unga får arbete efter avslutad gymnasieutbildning, eller att de arbetar vid sidan av studierna. Av Figur 17 framgår det att en hög andel unga i de nordiska länderna arbetar deltid och att deltidsarbetandet också ökat trendmässigt under perioden, främst i Danmark och Norge.

AKU undersöker i vilken mån personer arbetar deltid pga. de vill ha ett deltidsarbete eller om orsaken är att de inte kan få ett heltidsarbete. Det går dock inte att separera dem som vill ha heltidsjobb under hela året från dem som söker heltidsjobb på sommaren: att söka heltidssommarjobb är här detsamma som vilja ha heltid. Det går här heller inte att dela upp statistiken i 15-19 respektive 20-24 år. Det finns skäl att tro att fler i åldersgruppen 15-19 enbart vill ha extraarbete än i den äldre åldersgruppen pga. att de studerar i högre grad. I Finland och Sverige sökte 65 procent främst heltidsarbete. I de övriga nordiska länderna var andelarna lägre med drygt 40 procent i Danmark och Norge och ca 50 procent på Island. ${ }^{10}$

Viljan att ha ett sommarjobb kan påverkas av institutionella faktorer som t.ex. om studiemedel betalas ut under hela året eller om det är uppehåll under loven. Ett avbrott i studiemedelsfinansiering under loven innebär troligen ökade incitament att söka sommarjobb. Enbart i Danmark och

${ }^{10}$ Eurostat. 
på Island betalas studiemedel ut under hela året. Ungdomsarbetslösheten är mer säsongsbetonad när man inte får studiemedel på sommaren även om det kan finnas möjlighet att läsa sommarkurser etc. Det blir tydligt när man tittar på dem som avvaktar ett arbete som börjar inom tre månader. I Finland, Island och Sverige är andelen som avvaktar att påbörja ett arbete (över 20 procent) det andra kvartalet ett år högre än i Danmark och Norge (runt 10 procent). ${ }^{11}$

Figur 17: Deltidssysselsättning, 20-24 år

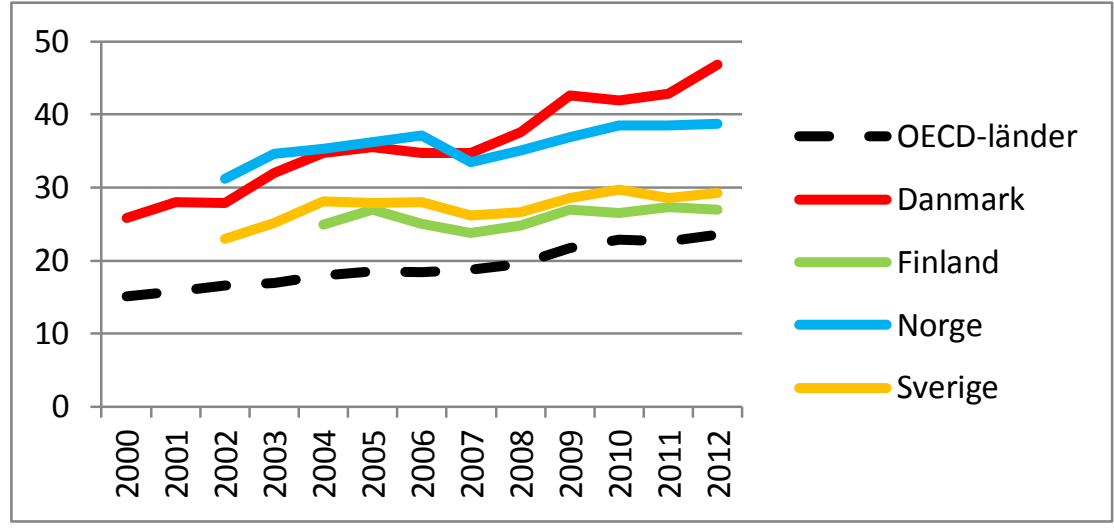

Anm.: Andelen av de anställda som arbetar deltid. Procent. Notera att skalan slutar vid 50 procent. Källor: AKU, SCB och OECD.

Fler unga än vuxna arbetar också i tidsbegränsade anställningar och andelen med tidsbegränsade utbildningar är högre i Finland och Sverige än i övriga nordiska länder och hela genomsnittet för OECD. Med undantag från Island har de nordiska länderna ett svagare anställningsskydd för tidsbegränsade anställningar än för tillsvidareanställningar eller fasta anställningar (se bilaga 4). Andelen tidsbegränsade anställningar har ökat trendmässigt i Sverige under den studerande perioden. 
Sverige har det starkaste anställningsskyddet för tillsvidareanställningar och störst skillnad i styrkan i anställningsskyddet mellan tillsvidare- och tidsbegränsade anställningar av de nordiska länderna (se Figur 39).

Figur 18: Tidsbegränsade anställningar, 15-24 år

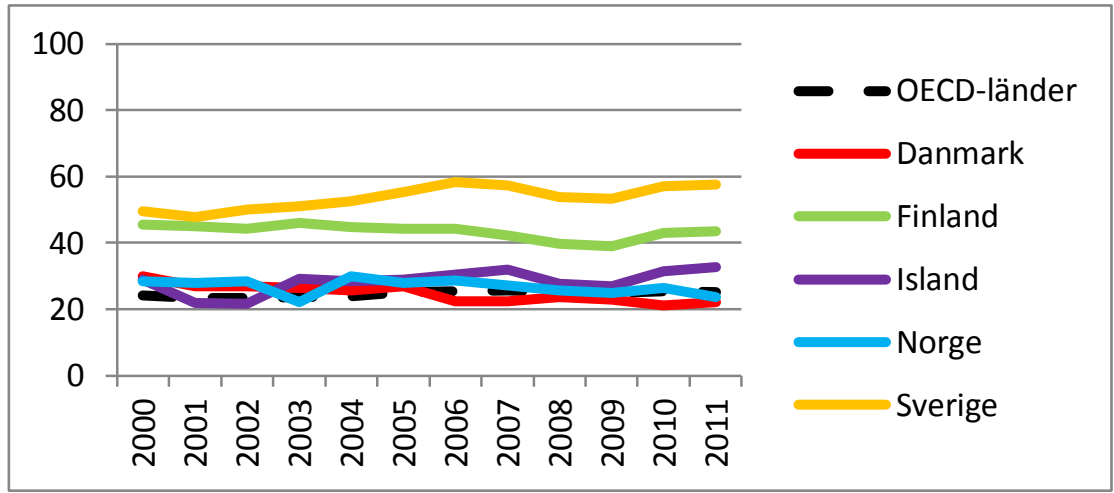

Anm.: Andelen tidsbegränsade anställningar av samtliga anställningar. Notera att åldersgruppen skiljer sig från 20-24.

Källa: AKU, OECD.

\subsection{Arbetslöshet}

Arbetslösheten i åldersgruppen 20-24 år följer samma mönster som åldersgruppen 15-19 år. Arbetslösheten är dock väsentligt lägre för åldersgruppen 20-24 år än i den yngre åldersgruppen, och variationerna mellan länderna har minskat. Den globala ekonomiska krisen syns tydligt i Figur 19, med en uppgång i arbetslöshet för alla nordiska länder från 2008. 
Figur 19: Arbetslöshet, totalt (a), efter kön (b) samt unga relativt vuxna (c)

Figur 19a: Arbetslöshet, totalt, 20-24 år

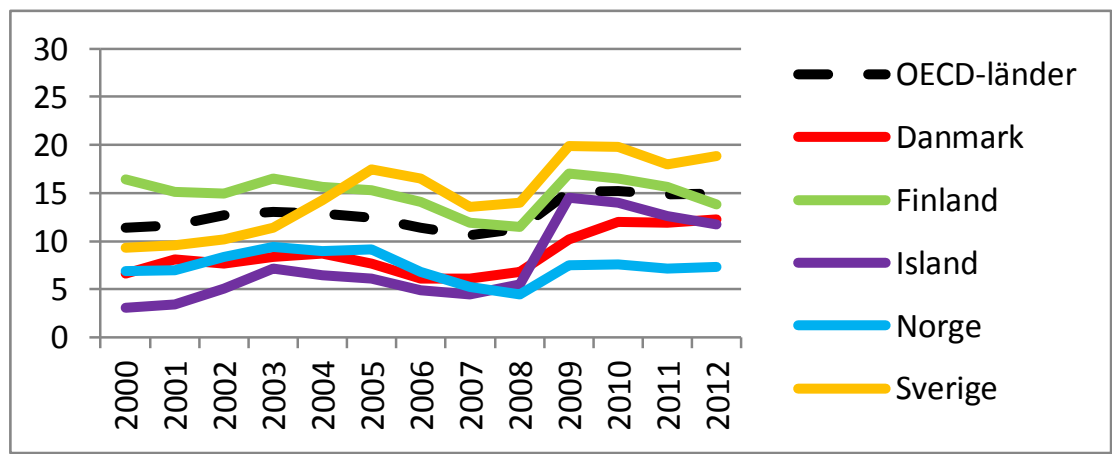

Anm.: Andelen arbetslösa av arbetskraften. Procent. Notera att skalan går till 30 procent. Källa: AKU, OECD.

Det finns betydande skillnader i andel arbetslösa mellan könen i denna åldersgrupp. I såväl de nordiska länderna (förutom Island) som i genomsnittet för hela OECD så är en högre andel män än kvinnor som är arbetslösa.

Figur 19b: Arbetslöshet för kvinnor och män, 20-24 år, 2012

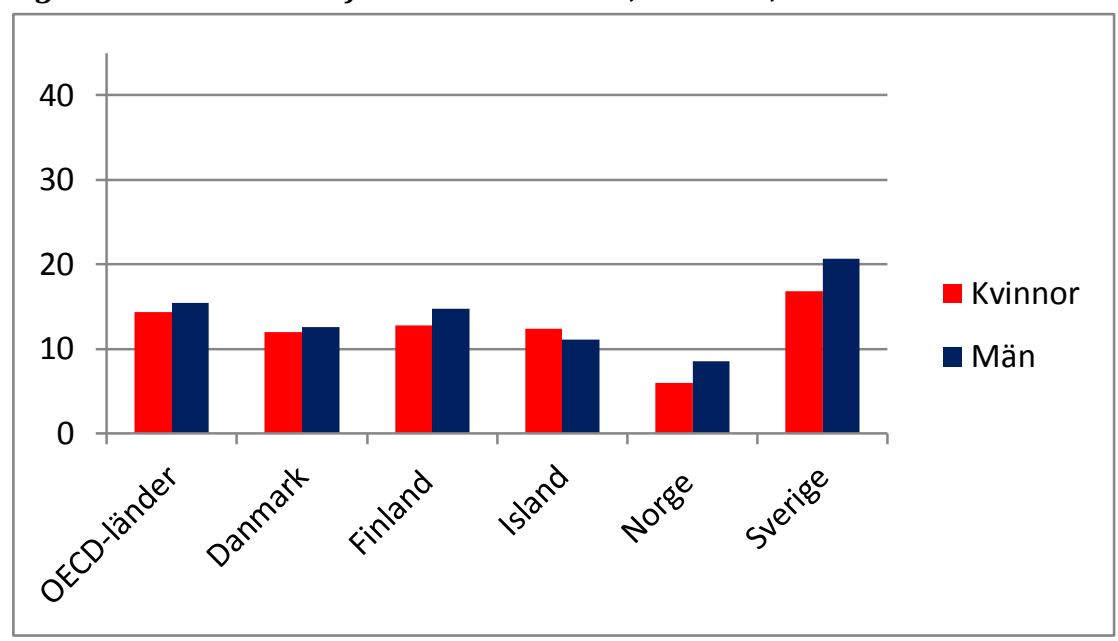

Anm.: Andelen arbetslösa av arbetskraften. Procent. Notera att skalan endast går till 40 procent. Källa: AKU, OECD. 
Den relativa arbetslösheten, dvs. arbetslösheten för unga relativt arbetslösheten för äldre som redovisas i Figur 19c, visar att unga i alla länder har en högre arbetslöshet än äldre. Det bekräftar att ungdomsarbetslösheten är ett generellt problem i alla länder. Kvoten mellan ungas och äldres arbetslöshet kan påverkas både om de ungas eller om de äldres arbetslöshet förändras.

Figur 19c: Arbetslöshet för unga (20-24 år) relativt äldre (25-64 år)

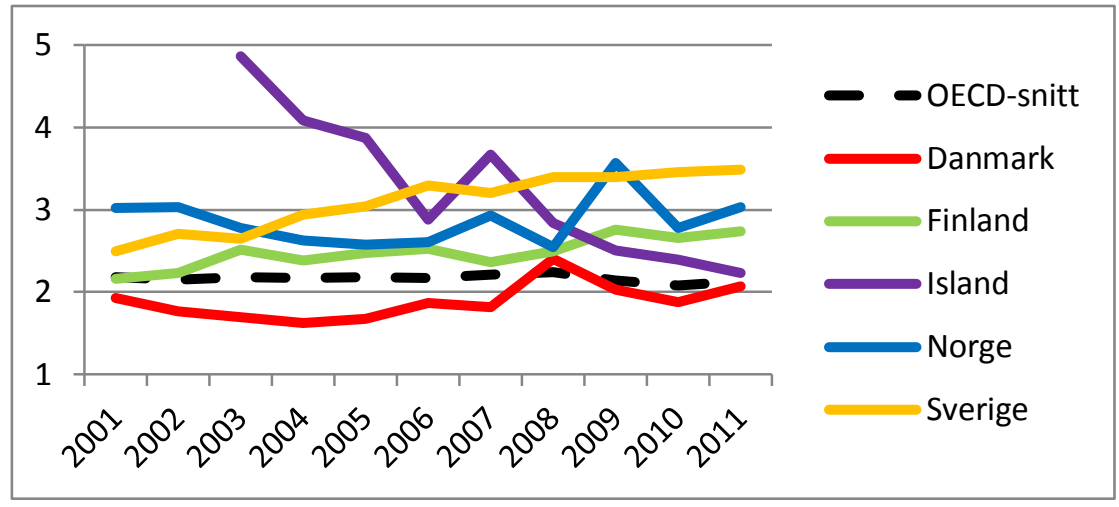

Anm.: Andelen arbetslösa av arbetskraften.

Källa: AKU, OECD.

Även i denna åldersgrupp är det en hög andel de arbetslösa som samtidigt studerar. Den är dock lägre än för den yngre åldersgruppen. 
Figur 20: Studerande arbetslösa, 20-24 år

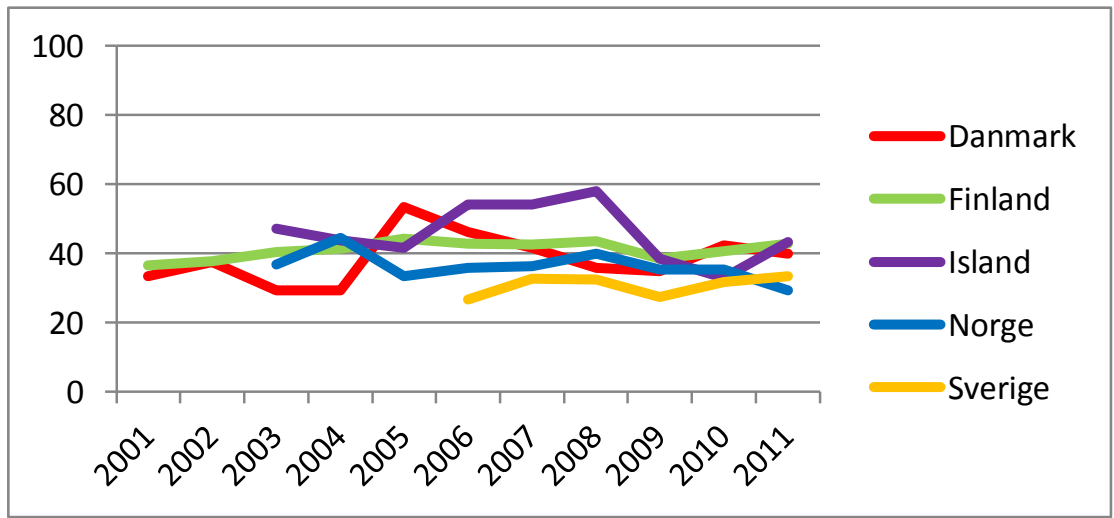

Anm.: Andelen heltidsstuderande av de arbetslösa. Procent.

Källa: SCB.

Arbetslösheten sjunker när heltidsstuderande exkluderas från de arbetslösa. Det illustreras i Figur 21 för åldersgruppen 20-24 år. Ökningen av arbetslöshet efter 2008 kvarstår när heltidsstuderande exkluderats från arbetslöshetsserien.

Figur 21: Arbetslöshet exklusive heltidsstuderande, 20-24 år

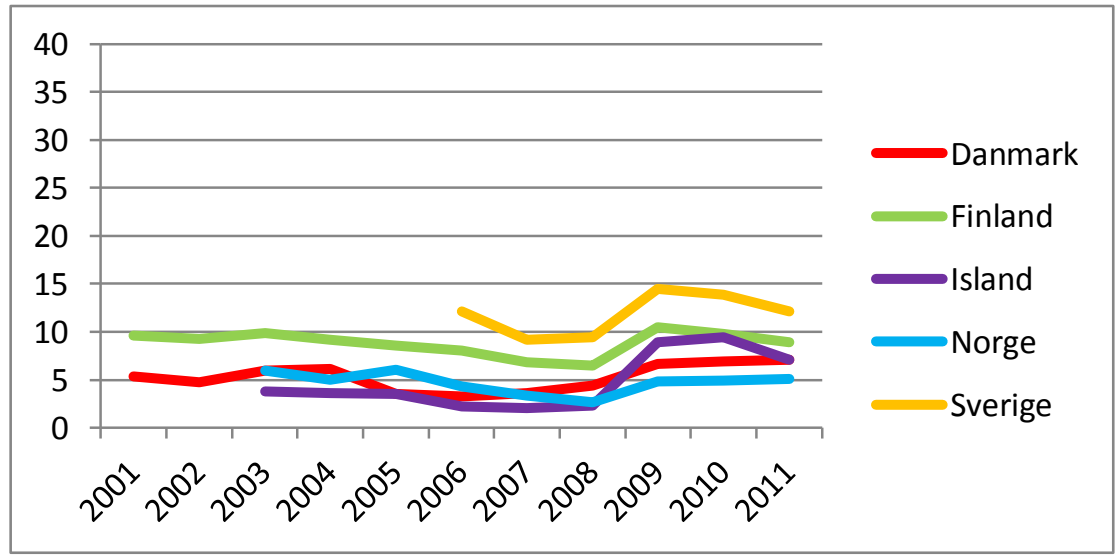

Anm.: Andelen heltidsstuderande av de arbetslösa. Procent.

Källa: OECD och SCB samt egna beräkningar. 
Även om ungdomar har en högre risk att bli arbetslösa än medelålders och äldre är arbetslöshetsperioderna oftast relativt korta. Figur 22 visar att mer än hälften av alla unga arbetslösa har varit arbetslösa förhållandevis kort tid, och att de nordiska länderna tycks ha fler korta arbetslöshetsperioder än övriga OECD-länder.12 En relativt sett lägre andel långtidsarbetslösa och en högre andel med korta arbetslöshetstider jämfört med äldre åldersgrupper medför att sannolikheten att lämna arbetslösheten är högre bland unga än bland äldre. Chansen att få ett arbete är dock inte alltid högre bland unga än bland medelålders eller äldre. Det kan förklaras av att unga i hög utsträckning växlar mellan arbete och studier.

Figur 22: Arbetslöshetstid under tre månader, 20-24 år

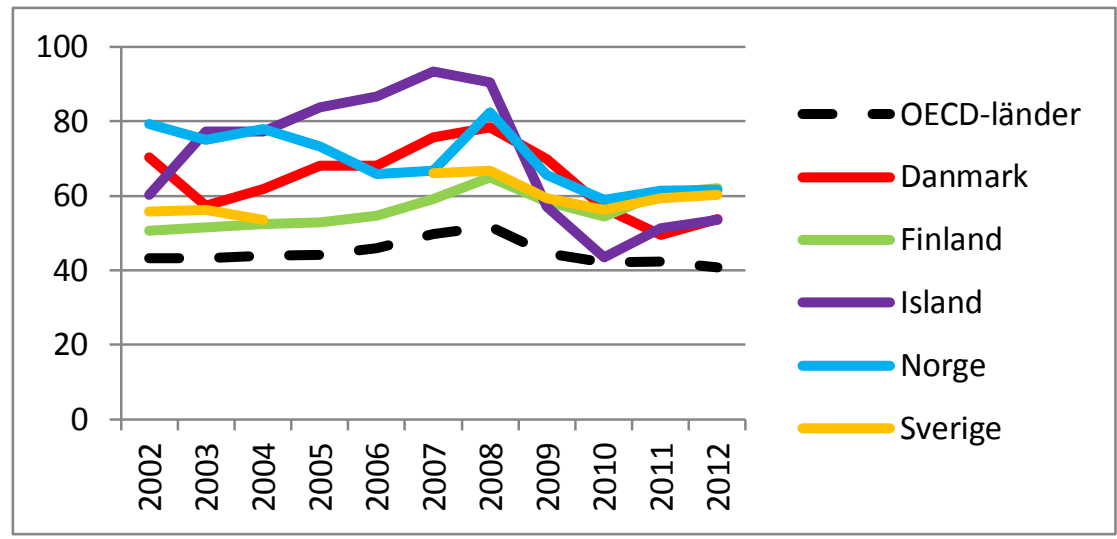

Anm.: Andelen av de arbetslösa som varit arbetslösa högst tre månader. Orsaken till tidsseriebrottet för Sveriges del var insamlingsproblem. Procent.

Källa: AKU, OECD.

\footnotetext{
12 Statistiken visar här inte andelen avslutade arbetslöshetstider, utan pågående arbetslöshetstider. Personer som är arbetslösa svarar på frågan om hur länge de har varit arbetslösa. De med långa arbetslöshetstider har större sannolikhet att komma med i urvalet än de med korta arbetslöshetsperioder. Det innebär att andelen med korta arbetslöshetstider kan vara underskattad.
} 
Det finns skäl bekymra sig för långa arbetslöshetstider eftersom en individs jobbchanser minskar med tiden som arbetslös. De nordiska länderna har överlag har en lägre andel långtidsarbetslösa av de arbetslösa jämfört med snittet för OECD (se Figur 23). På Island ökade andelen långtidsarbetslösa kraftigt efter bankkrisen och den globala ekonomiska krisen men har återigen börjat sjunka.

Figur 23: Långtidsarbetslöshet, totalt (a) och efter kön (b), 20-24 år

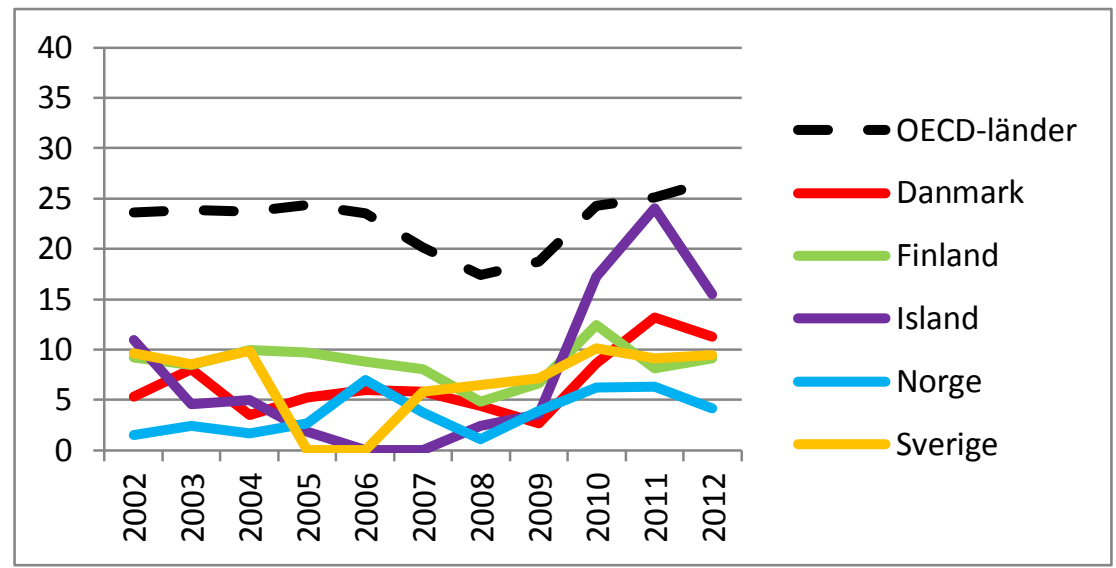

Anm.: Andelen arbetslösa som varit arbetslösa mer än ett år. Procent. Notera att skalan endast går till 40 procent.

Källa: AKU, OECD.

Förutom på Island så är långtidsarbetslösheten är högre bland unga män än för unga kvinnor under 2011. Detta mönster har varierat över tid i de flesta nordiska länderna. Män har drabbats relativt sett hårdare av finanskrisen än av befolkningen som helhet. 
Figur 23b: Långtidsarbetslöshet, efter kön (b), 20-24 år, 2011

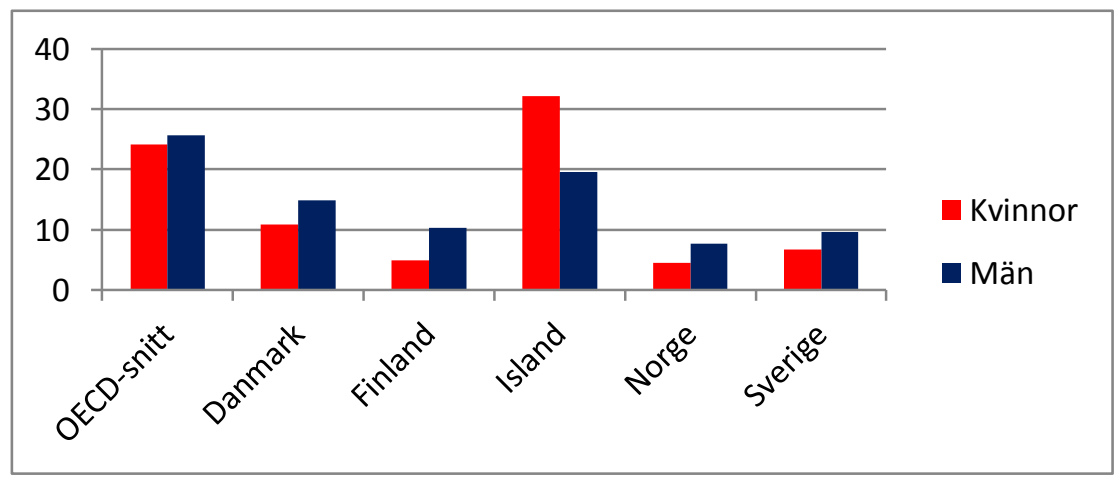

Anm.: Andelen arbetslösa som varit arbetslösa mer än ett år. Procent. Notera att skalan endast går till 40 procent.

Källa: AKU, OECD.

Vissa grupper, bl.a. de som inte har fullföljt någon gymnasieutbildning (Figur 24), utrikes födda (Figur 25) och personer som har funktionshinder som medför nedsatt arbetsförmåga har större svårigheter att etablera sig på arbetsmarknaden och har en högre risk för långtidsarbetslöshet än andra. Grupperna är mycket heterogena och är ofta överlappande. Dessa grupper kan dessutom halka efter ytterligare i konjunkturåterhämtningar när sysselsättningen tar fart. Då finns många sökanden som har färdigt gymnasium, och som får jobb före dem som saknar gymnasieexamen. 
Figur 24: Arbetslöshet för alla respektive de som inte fullföljt gymnasiet, 1824 respektive $20-24$ år, 2011

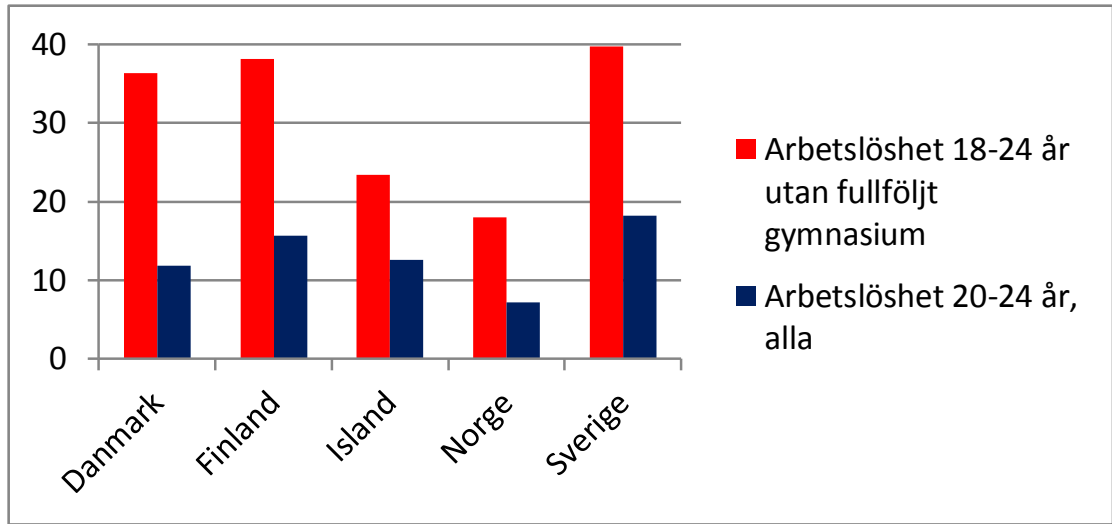

Anm.: Andelen arbetslösa av arbetskraften. Procent. Notera att åldersgruppsindelning för de som inte fullföljt gymnasiet skiljer sig från 20-24 år och att skalan endast går till 40 procent.

Källa: Eurostat.

Figur 25: Arbetslöshet för inrikes och utrikes födda, 20-24 år, 2012

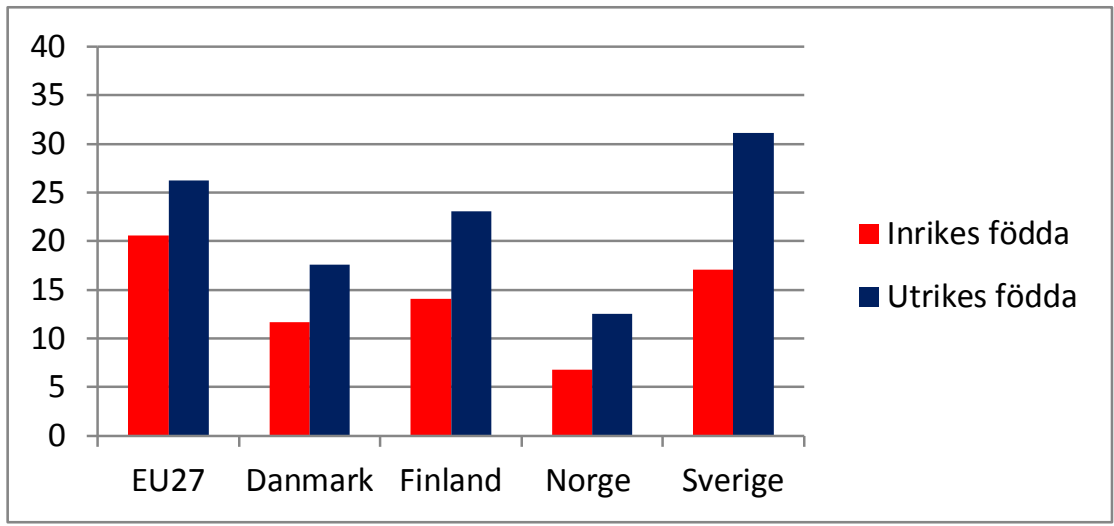

Anm.: Andelen arbetslösa av arbetskraften. Uppgifter för utrikes födda saknas för Island. Procent. Notera att skalan endast går till 40 procent.

Källa: OECD. 


\section{Not in education, employment or training - NEET}

Eftersom det de gängse arbetslöshetsmåtten inte är oproblematiska att använda för unga så undersöktes NEET-måttet även för denna åldersgrupp. För de nordiska länderna var det en lägre del som tillhörde NEET jämfört med ett genomsnitt av EU27-länderna (se Figur 26). Det en ökning av antalet unga som tillhör gruppen jämfört med åldersgruppen 1519. Kunskapen om vad denna grupp gör är mycket begränsad, men den kan utgöras av de grupper på arbetsmarknaden som upplever störst problem och som blir försörjda av sina föräldrar, unga som har annan okänd försörjning men också av unga som befinner sig utomlands.

Figur 26: Varken i utbildning eller i sysselsättning (NEET), 20-24 år, 2012

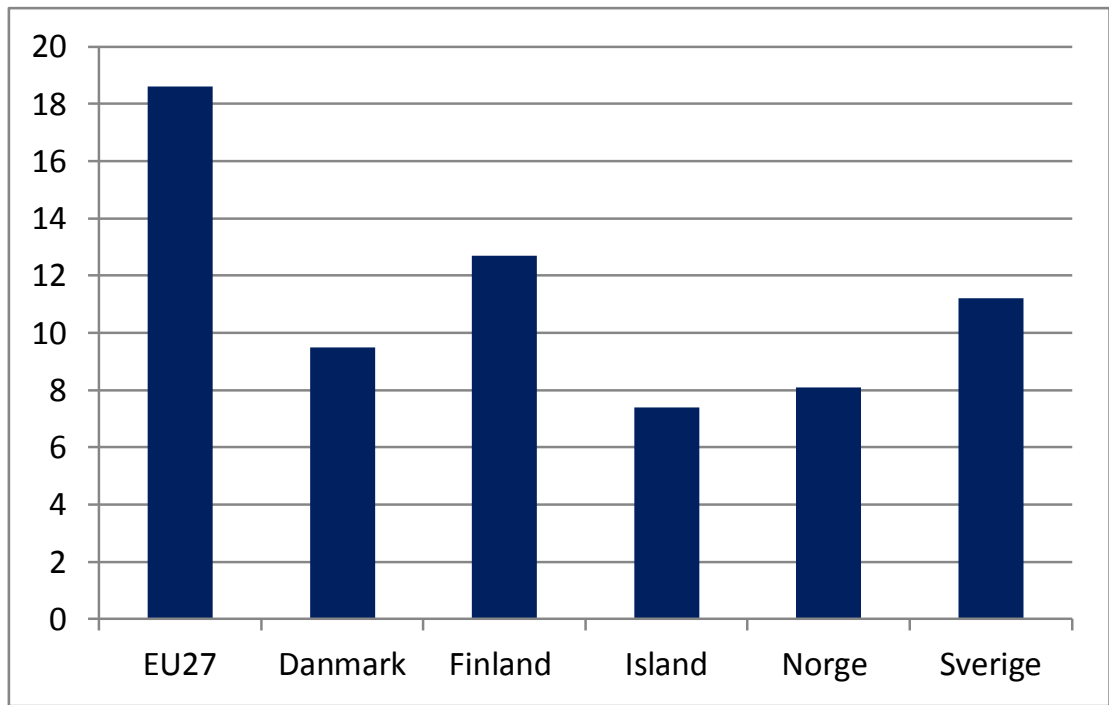

Anm.: Andelen av befolkningen som inte är i utbildning eller sysselsättning (NEET). Notera att skalan går till 20 procent.

Källa: Eurostat. 


\section{Ungas löner och försörjning}

Detta avsnitt redovisar viss bakgrundsdata på tänkbara förklaringar till varför en högre andel av unga än de äldre är arbetslösa (se Figur 19c). Det finns ett par ofta diskuterade möjliga förklaringar. ${ }^{13} \mathrm{En}$ är att lönenivåerna för unga inte med säkerhet är i balans med ungdomars produktivitet. Strikta regler för uppsägningar av fastanställda kan öka viljan att hellre anställa studenter på tillfälliga kontrakt än att fastanställa färdigutbildade ungdomar. I detta avsnitt redovisas också viss statistik om unga som står långt ifrån arbetsmarknaden; unga med försörjningsstöd eller förtidspension.

\section{Löner}

Eftersom unga jämfört med medelålders på arbetsmarknaden har en konkurrensnackdel genom att de har mindre erfarenhet och så har de allt annat lika lägre förväntad produktivitet. $O m$ inte produktivitetsskillnaden kompenseras genom lägre ingångslöner för unga kan det medverka till att den relativa ungdomsarbetslösheten blir högre eftersom arbetsgivarnas personalkostnader ökar. ${ }^{14}$

I de nordiska länderna regleras lägstalönerna genom förbundsvisa förhandlingar mellan arbetsgivare och fackföreningar till skillnad från många andra länder där lägstalöner regleras genom lagstiftning. De nordiska lägstalönerna är mycket svåröverblickbara eftersom de sätts i olika avtal mellan arbetsgivare och arbetstagare. Det finns inte offentlig statistik eller annan

\footnotetext{
${ }^{13}$ Här värd eras inte giltigheten i de olika möjliga förklaringarna eftersom det går utöver syftet med denna rapport. Annan litteratur som diskuterar detta vidare är bl.a. Skedinger (2007), Nordström Skans (2009) och Olofsson och Wadensjö (2012) och referenser däri.

14 Effekten av höga lägstalöner på sysselsättningen är dock inte entydig. Höga lägstalöner kan teoretiskt ha två effekter. Höga lägstalöner kan innebära att studenter väljer att inte fullfölja stu dier utan istället tar ett arbete. I det fallet ökar sysselsättningen. Höga lägstalöner kan också minska efterfrågan på unga som i förväntan är mindre produktiva eftersom de saknar arbetslivserfarenhet. Höga lägstalöner kan också öka efterfrågan på arbetskraft om arbetskraftsefterfrågan kännetecknas av monopsoni.
} 
allmänt tillgänglig statistik som visar vilken nivå de ligger på och ofta skiljer sig lägstalönerna åt betingade på yrke, erfarenhet eller ålder.

En lägstalön definierar den lägsta nivå under vilken lönen inte får sjunka. Lägstalönerna i olika avtal är ofta differentierade efter ålder och erfarenhet. Den gäller således för alla även om den främst berör nyinträdande på arbetsmarknaden. Om den lägsta avtalade lönenivån är hög bidrar det till höga löner för lågavlönade. Lägstalöner kan också påverka lönerna för anställda högre upp i lönefördelningen, beroende på produktionsteknologi och hänsynstagande till relativa löner. De relativa lönerna redovisas här med det s.k. minimilönebettet, som är definierat som kvoten mellan lägstalönen och genomsnittslönen. Minimilönebettet ger inte upplysning om hur många personer som faktiskt har en lön lika med eller nära minimilönen eller hur många personer som berörs av förändringar i lägstalöner.

Här används en nyligen genomförd nordisk undersökning av lägstalöner och minimilönebett för en av tjänstesektors stora yrkesgrupper i detaljhandeln, arbetare i service- och försäljningsyrken, för att ge en bild av lägstalöner och minimilönebett, se Tabell 4.

Tabell 4: Lägstalöner och minimilönebett, År 2011, för arbetare i service- och försäljningsyrken

\begin{tabular}{lcc}
\hline Land & Minimilönebett & Lägstalön, ppt SEK \\
\hline Danmark & 71 & 18946 \\
Finland & 72 & 15888 \\
Island & 66 & 10715 \\
Norge & 77 & 21026 \\
Sverige & 79 & 17325 \\
Genomsnitt för ett urval av & 63 & 10949 \\
länder & & \\
\hline
\end{tabular}

Anm.: Lägstalön för heltid före skatt per månad i köpkraftskorrigerad SEK, samt relativt genomsnittlig månadslön för heltid före skatt (minimilönebett).

Källa: Berge (2013). Handelsanställdas förbund.

\footnotetext{
15 Länderna som ingår i det oviktade genomsnittet är förutom de nordiska Frankrike, Slovenien, Luxemburg, Turkiet, Portugal, Litauen, Polen, Nederländerna, Storbritannien, Irland, Lettland, Slovakien, Belgien, Malta, Bulgarien, Estland, Rumänien, Tjeckien, Spanien, Ungern, Kroatien och USA. Länderna är här uppräknade rangordnade efter var i lönefördelningen minimilönebettet biter, från högt i fördelningen till lågt. Frankrikes minimilönebett är 72 procent och USA:s 37 procent.
} 
Nivån på lägstalönerna i de nordiska länderna för arbetare i service- och försäljningsyrken, mätt med minimilönebettet, är hög i en internationell jämförelse för de flesta nordiska länderna.

Tabell 5 visar både på andelen som tjänar minst och på lönespridningen i de nordiska länderna. ${ }^{16} \mathrm{Av}$ de tre länder där det finns jämförbar information om andelen som tjänar under två tredjedelar av medianlönen har Island högst andel som tjänar relativt lite. Ungdomar i Danmark och Finland tjänar relativt mycket, något som vi också kunde se i Tabell 4 med relativt höga minimilönebett för Finland och Danmark och lägre på Island.

Relationen mellan 9:e och 1:a decilen visar hur stor lönespridningen är i ett land. I länder med en hög kvot är skillnaden mellan höga och låga löner stor. I länder med låg kvot är lönespridningen liten. Lönespridningen är relativ liten i alla nordiska länder. I de jämförda länderna är Sverige ett av de länder som har lägst lönespridning. Island har den klart högsta lönespridningen. På Island finns det dock bara data fram tom 2008. Då hade Island en bankkris som, i kombination med den globala ekonomiska krisen, fick stora negativa konsekvenser för sysselsättning och arbetslöshet. Det kan ha påverkat de relativa lönerna också.

${ }^{16}$ Ett annat sätt att mäta skulle vara att använda ginikoefficienten. Den mäts ofta som disponibel inkomst efter skatter och transfereringar, till skillnad från lön som vi valt att mäta här. 
Tabell 5: Andel med låg inkomst och deciler av löneinkomst ${ }^{17}$

\begin{tabular}{|c|c|c|c|c|c|c|c|c|c|c|c|c|c|}
\hline & & 2000 & 2001 & 2002 & 2003 & 2004 & 2005 & 2006 & 2007 & 2008 & 2009 & 2010 & 2011 \\
\hline \multirow[t]{3}{*}{ Danmark } & Andel med låg lön ${ }^{18}$ & 8,8 & 10,5 & 10,5 & 11,5 & 10,7 & 11,3 & 11,9 & 12,0 & 13,0 & 13,6 & 13,4 & - \\
\hline & Decil 5/Decil 1 & 1,5 & 1,5 & 1,5 & 1,5 & 1,5 & 1,5 & 1,5 & 1,5 & 1,6 & 1,6 & 1,6 & - \\
\hline & Decil 9/ Decil 1 & 2,5 & 2,6 & 2,6 & 2,6 & 2,6 & 2,6 & 2,7 & 2,7 & 2,7 & 2,7 & 2,8 & - \\
\hline \multirow[t]{3}{*}{ Finland } & Andel med låg lön & - & 4,6 & 7,3 & 6,4 & 7,0 & 6,9 & 7,5 & 7,9 & 8,5 & 8,5 & 8,1 & - \\
\hline & Decil 5/ Decil 1 & 1,4 & 1,4 & 1,4 & 1,4 & 1,4 & 1,4 & 1,4 & 1,4 & 1,5 & 1,5 & 1,4 & - \\
\hline & Decil 9/ Decil 1 & 2,4 & 2,4 & 2,4 & 2,4 & 2,4 & 2,5 & 2,5 & 2,6 & 2,6 & 2,6 & 2,5 & - \\
\hline \multirow[t]{3}{*}{ Island } & & - & - & - & - & 18,7 & 17,6 & 17,1 & 17,4 & 16,7 & - & - & - \\
\hline & Decil 5/ Decil 1 & - & - & - & - & 1,8 & 1,8 & 1,8 & 1,8 & 1,8 & - & - & - \\
\hline & Decil 9/ Decil 1 & - & - & - & - & 3,1 & 3,1 & 3,1 & 3,2 & 3,2 & - & - & - \\
\hline \multirow[t]{3}{*}{ Norge } & & - & - & - & - & - & - & - & - & - & - & - & - \\
\hline & Decil 5/ Decil 1 & 1,4 & 1,4 & 1,5 & 1,4 & 1,5 & 1,5 & 1,5 & 1,5 & 1,5 & 1,6 & 1,6 & 1,6 \\
\hline & Decil 9/ Decil 1 & 2,0 & 2,1 & 2,1 & 2,1 & 2,1 & 2,1 & 2,2 & 2,2 & 2,3 & 2,3 & 2,3 & 2,3 \\
\hline \multirow[t]{3}{*}{ Sverige } & & - & - & - & - & - & - & - & - & - & - & - & - \\
\hline & Decil 5/ Decil 1 & 1,4 & 1,4 & 1,4 & 1,4 & 1,4 & 1,4 & 1,4 & 1,4 & 1,4 & 1,4 & 1,4 & - \\
\hline & Decil 9/ Decil 1 & 2,3 & 2,3 & 2,3 & 2,3 & 2,2 & 2,2 & 2,3 & 2,3 & 2,3 & 2,3 & 2,2 & - \\
\hline
\end{tabular}

Anm.: Löneinkomsten är bruttolöneinkomst.

Källa: OECD.

17 Deciler är en metod för att beskriva spridning i en fördelning. Deciler delar upp en fördelning i 10 lika stora delar. Deciler innebär en uppdelning av värden i proportioner om 10 procent. Observationerna är sorterade från lägsta till högsta värde. En indelning i deciler innebär en uppdelning decil 1 till decil 9 . Decil 5 motsvarar medianen i en fördelning och har 50 procent av observationerna på respektive sida om sig.

${ }^{18}$ Andel med låg lön definieras som andelen av den totala (beroende) sysselsättningen som tjänar mindre än två tredjedelar av medianinkomsten. 


\section{Transfereringar}

För unga med liten anknytning till arbetsmarknaden kan försörjningen bestå av försörjningsstöd eller förtidspension. Tabell 6 redovisar andelen med förtidspension och försörjningsstöd.

De unga som mottar försörjningsstöd är särskilt utsatta också eftersom de kan hamna utanför arbetsmarknaden mer permanent när att de inte upparbetar rätt till inkomstprövade bidrag under tiden med behovsprövade bidrag. För de allra flesta unga som hamnar i någon form av förtidspension blir det en permanent situation för resten av livet. Nästan ingen går från förtidspension till arbete i de nordiska länderna.

Tabell 6: Unga med försörjningsstöd eller förtidspension

\begin{tabular}{lrr}
\hline & $\begin{array}{r}\text { Unga 18-24 som uppbär } \\
\text { försörjningsstöd }\end{array}$ & $\begin{array}{r}\text { Unga 20-34 som uppbär } \\
\text { förtidspension }\end{array}$ \\
\hline Danmark & 10 & 1,8 \\
Finland & 11 & 1,8 \\
Island & 6 & 3,3 \\
Norge & 5,5 & 2,0 \\
Sverige & 9 & 2,6 \\
\hline
\end{tabular}

Anm.: Andel av alla unga i åldersklasserna. Procent.

Källa: Halvorsen (2012). 



\section{Unga vuxna 25-29 år}

\subsection{En samlad bild av utbildning och arbete för unga vuxna $25-29$ år ${ }^{19}$}

I Figur 27 redovisas ungas huvudsakliga aktivitet i utbildningssystemet och på arbetsmarknaden. I jämförelse med de yngre åldersgrupperna är det här en låg andel som studerar, och en hög andel som är sysselsatt. Det är dock fortfarande många om studerar. I avsnittet om genomströmning $\mathrm{i}$ högre utbildning beskrevs att medianåldern för att ta examen från eftergymnasial utbildning är hög i de nordiska länderna (se Figur 15). Andelen arbetslösa och inaktiva har också ökat i denna åldersgrupp i förhållande till de yngre. Notera att arbetslösheten i figuren skiljer sig från den officiella definitionen enligt International Labour Organizations (ILO) på arbetslöshet dels genom att de arbetslösa som samtidigt studerar räknats bort och dels genom att antalet arbetslösa relateras till befolkningen i stället för till arbetskraften. Båda dessa faktorer sänker arbetslöshetsnivån jämfört bl.a. med Figur 30 som beskriver arbetslösheten och som bygger på ILO:s definitioner.

${ }^{19}$ Alla variabler som redovisats för de yngre åldersgrupperna finns inte tillgängliga i den åldersuppdelningen som används för de tidigare åldersgrupperna. Det gäller för t.ex. långtidsarbetslöshet. 
Figur 27: Vad unga vuxna 25-29 år huvudsakligen gör, 25-29 år, 2010

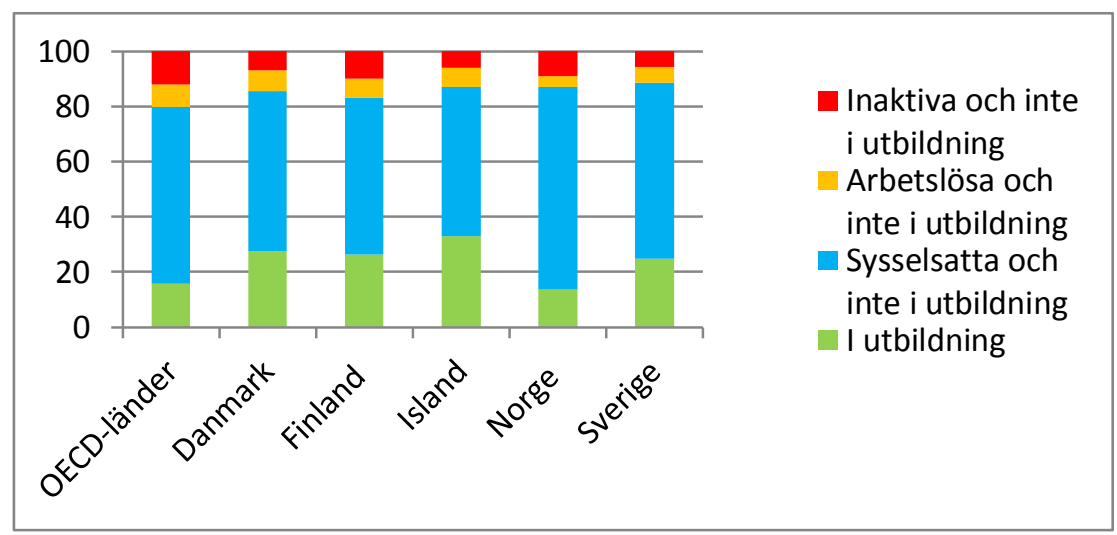

Anm.: Andelen av alla unga i åldersgruppen i en viss aktivitet. Procent.

Källa: Data är sammansatt från from Network on Outcomes of Learning (LSO) nätverkets särskilda datainsamling, Adult Learning Working Group, OECD. 


\subsection{Utbildning}

Avståndet i studerandegrad mellan de nordiska länderna och OECD är stort (se Figur 28a). I alla nordiska länder är det fler kvinnor än män som studerar (se Figur 28b).

Figur 28: Studerandegrad, totalt (a) och efter kön (b)

Figur 29a: Studerandegrad, totalt, 25-29 år

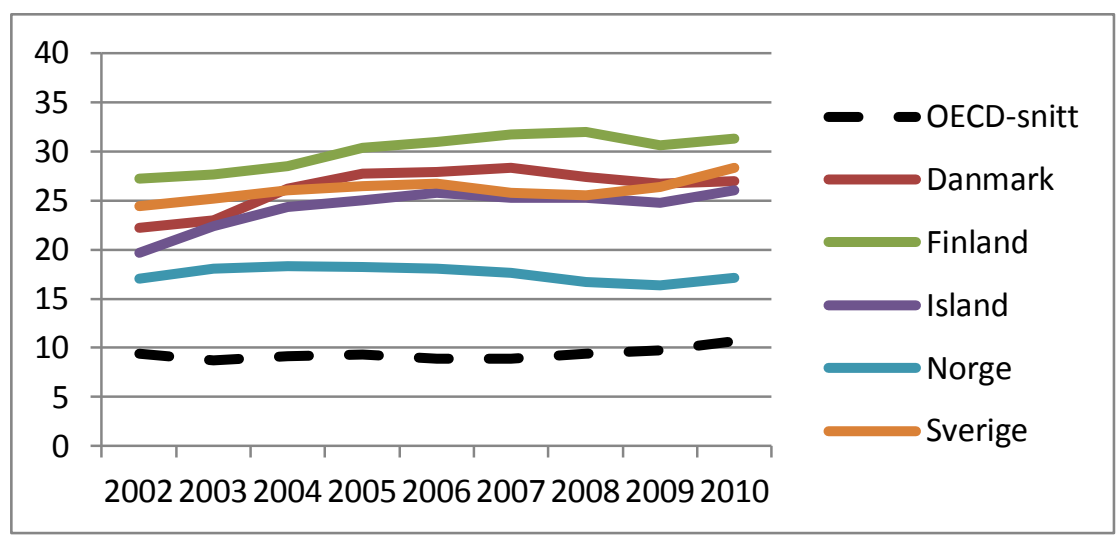

Anm.: Andelen studerande i åldersgruppen. Procent. Notera att skalan endast går till 40 procent. Källa: UNESCO-OECD-Eurostat (UOE) datainsamling i kombination med registerbaserad administrativ statistik, OECD:s databaser samt egen bearbetning. 
Figur 29b: Studerandegrad för kvinnor och män, 25-29 år, 2010

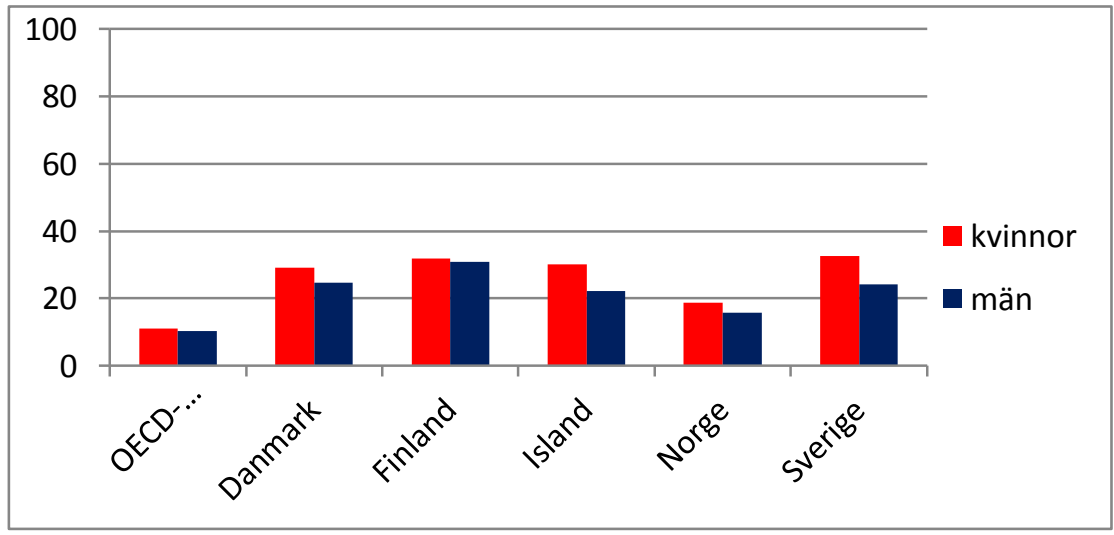

Anm.: Andelen studerande i åldersgruppen. Procent.

Källa: UNESCO-OECD-Eurostat (UOE) datainsamling i kombination med registerbaserad administrativ statistik, OECD:s databaser samt egen bearbetning.

\subsection{Sysselsättning}

Den höga sysselsättningsgraden för unga vuxna 25-29 år indikerar att alltfler etablerar sig med stigande ålder. Figur 29 visar att skillnaden mellan de nordiska länderna minskade ytterligare i åldersgruppen 25-29 år. En relativt hög andel är fortfarande i högre utbildning i denna åldersgrupp. 
Figur 29: Sysselsättningsgrad, totalt (a) och efter kön (b)

Figur 30a: Sysselsättningsgrad, totalt, 25-29 år

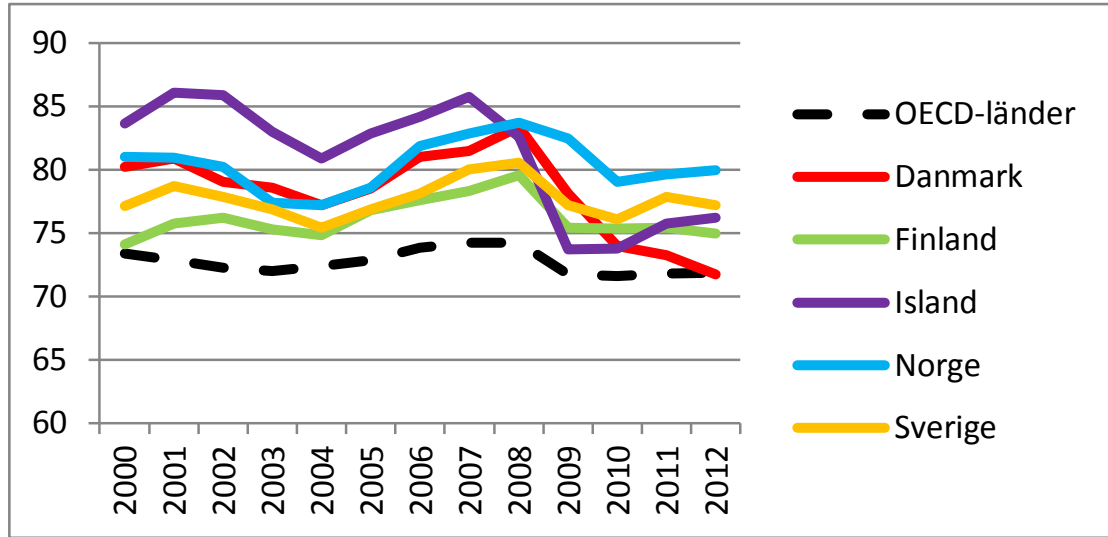

Anm.: Andelen sysselsatta i befolkningen. Procent. Notera att skalan går mellan 60 och 90 procent. Källor: AKU, OECD.

Figur 30b: Sysselsättningsgrad för kvinnor och män, 25-29 år, 2012

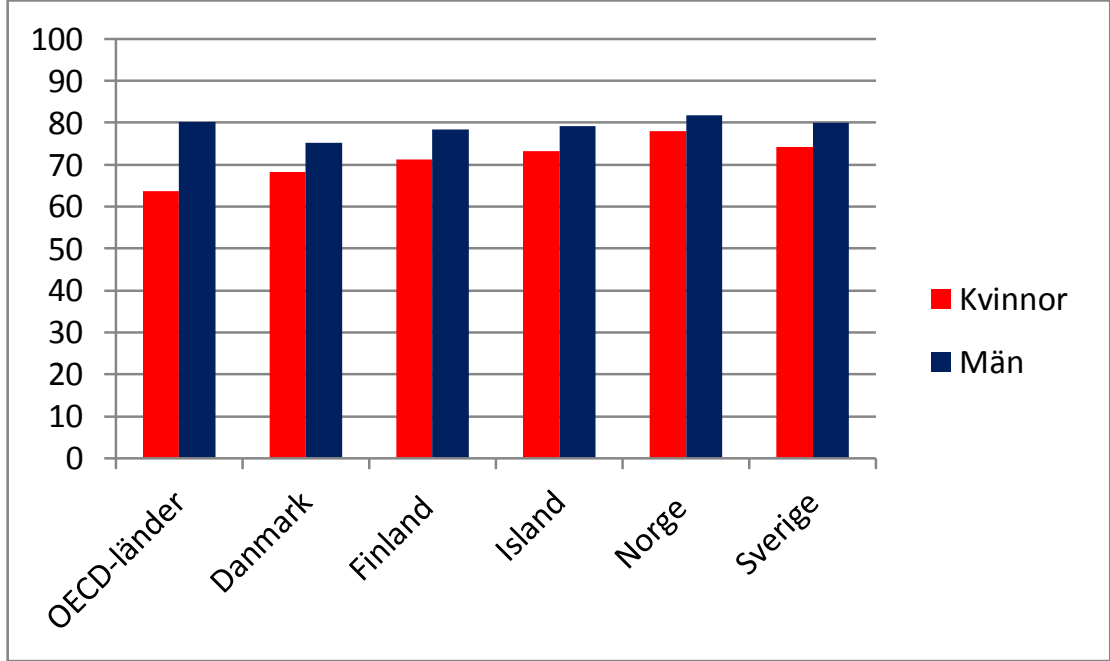

Anm.: Andelen sysselsatta i befolkningen. Procent.

Källa: AKU, OECD. 


\subsection{Arbetslöshet}

Variationerna i arbetslöshet mellan länderna har minskat i åldersgruppen 25-29 år jämfört med de yngre åldersgrupperna. Könsskillnaderna i arbetslöshet i denna åldersgrupp är små, män är i något högre grad arbetslösa i de nordiska länderna.

Figur 30: Arbetslöshet, totalt (a) och efter kön (b)

Figur 31a: Arbetslöshet, totalt, 25-29 år

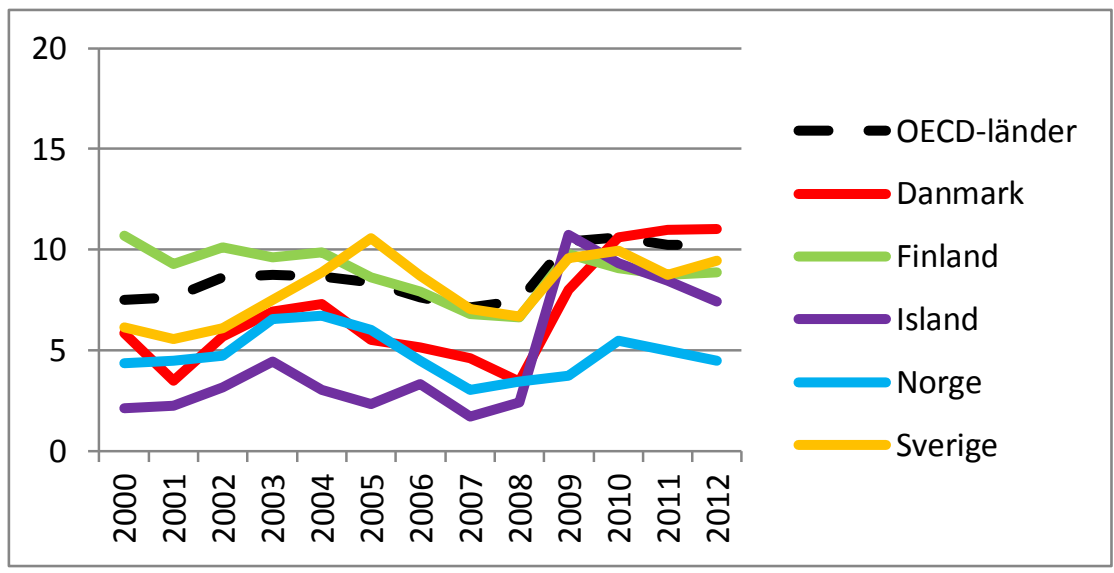

Anm.: Andelen arbetslösa av arbetskraften. Procent. Notera att skalan endast går till 40 procent. Källa: AKU, OECD. 
Figur 31b: Arbetslöshet för kvinnor och män, 25-29 år, 2012

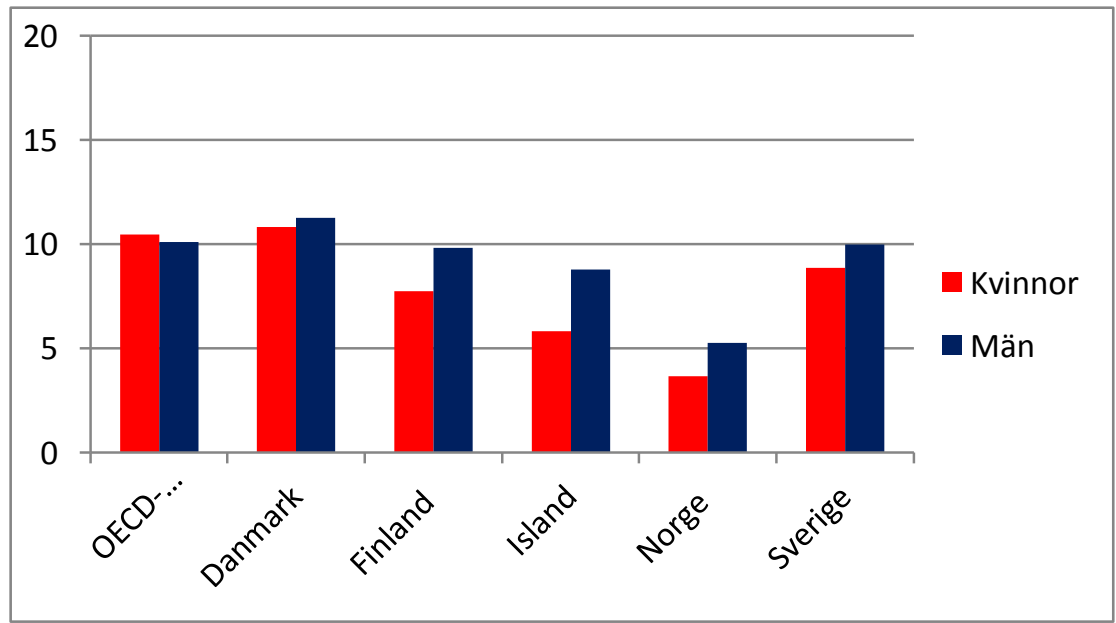

Anm.: Andelen arbetslösa av arbetskraften. Procent. Notera att skalan endast går till 20 procent. Källa: AKU, OECD. 



\section{Unga vuxna 30-34 år}

\subsection{Utbildning}

Det är en lägre andel som studerar i denna åldersgrupp än i åldersgruppen 25-29 år (se Figur 31a). Det är i princip samma rangordning mellan länderna i studerandegrad. Snittet för hela OECD ligger återigen en bit lägre än för de nordiska länderna. Det är som liksom tidigare fler kvinnor än män som studerar, något som illustreras i Figur 32b.

Figur 31: Studerandegrad, totalt (a) och efter kön (b)

Figur 32a: Studerandegrad, totalt, 30-34 år

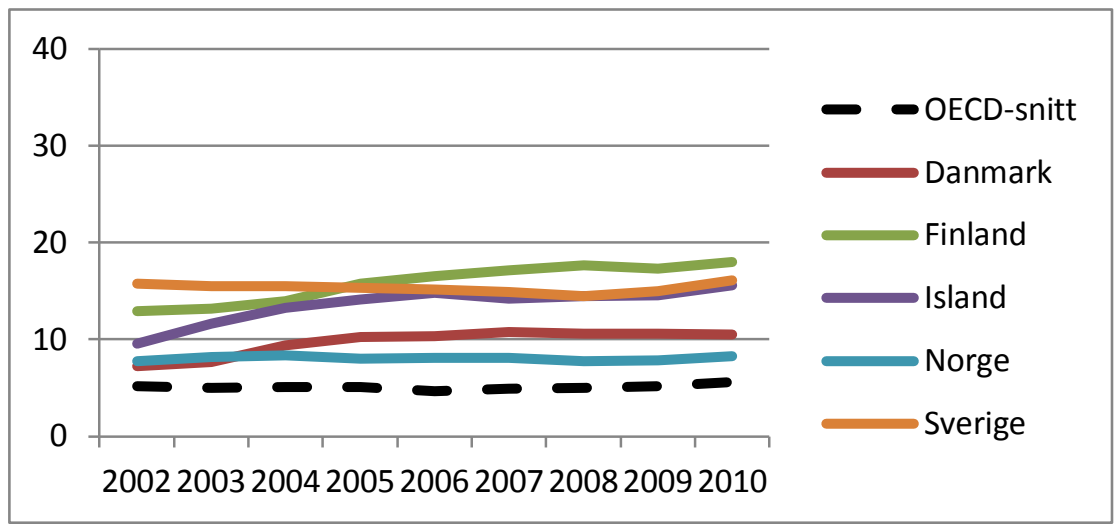

Anm.: Andelen studerande i åldersgruppen. Procent. Notera att skalan endast går till 40 procent. Källa: UNESCO-OECD-Eurostat (UOE) datainsamling i kombination med registerbaserad administrativ statistik, OECD:s databaser samt egen bearbetning. 
Figur 32b: Studerandegrad för kvinnor och män, 30-34 år, 2010

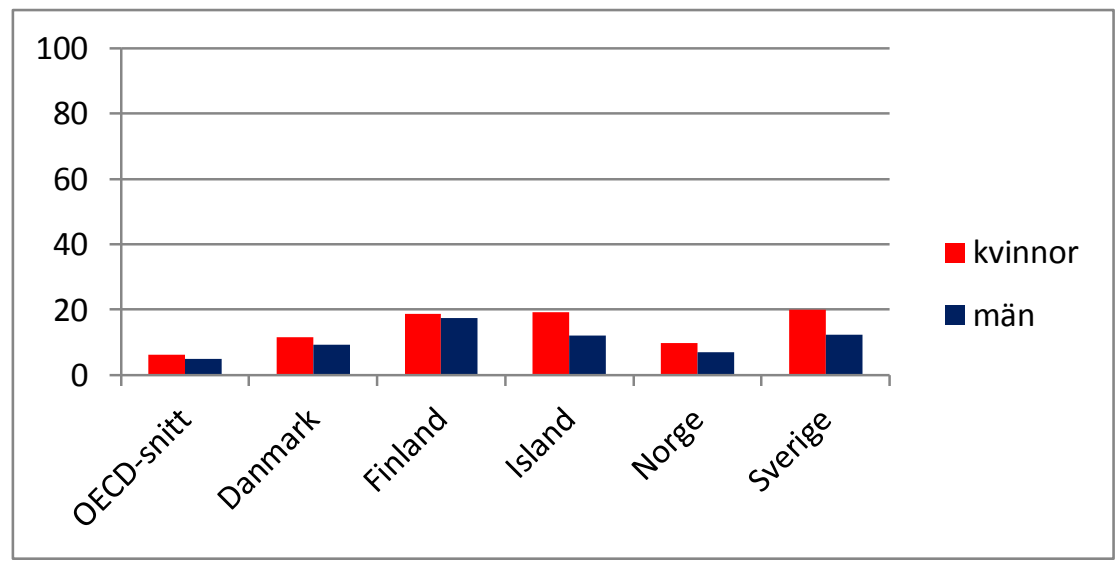

Anm.: Andelen studerande i åldersgruppen. Procent.

Källa: UNESCO-OECD-Eurostat (UOE) datainsamling i kombination med registerbaserad administrativ statistik, OECD:s databaser samt egen bearbetning. 


\subsection{Sysselsättning}

Figur 32 visar att sysselsättningsgraden för de nordiska länderna i denna åldersgrupp har ökat ytterligare jämfört med de tidigare åldersgrupperna. Rangordningen mellan länderna har ändrats, bl.a. är sysselsättningsgraden för Sverige högre jämfört med den för de andra länderna. Figur 32b visar att det i alla länderna är män som har en högre sysselsättningsgrad än kvinnor. Det är också här avståndet till OECD syns tydligast - det kvinnliga arbetskraftsdeltagandet i de nordiska länderna är högt jämfört med OECD.

Figur 32: Sysselsättningsgrad, totalt (a) och efter kön (b)

Figur 33a: Sysselsättningsgrad, totalt, 30-34 år

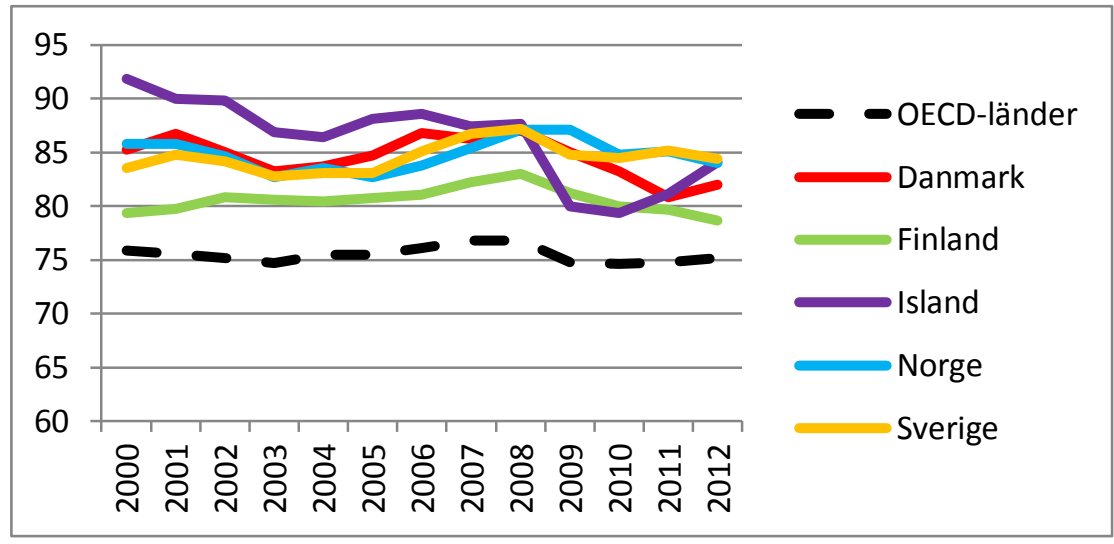

Anm.: Andelen sysselsatta i befolkningen. Procent. Notera att skalan går mellan 60 och 95 procent. Källa: AKU, OECD. 
Figur 33b: Sysselsättningsgrad för kvinnor och män, 30-34 år, 2012

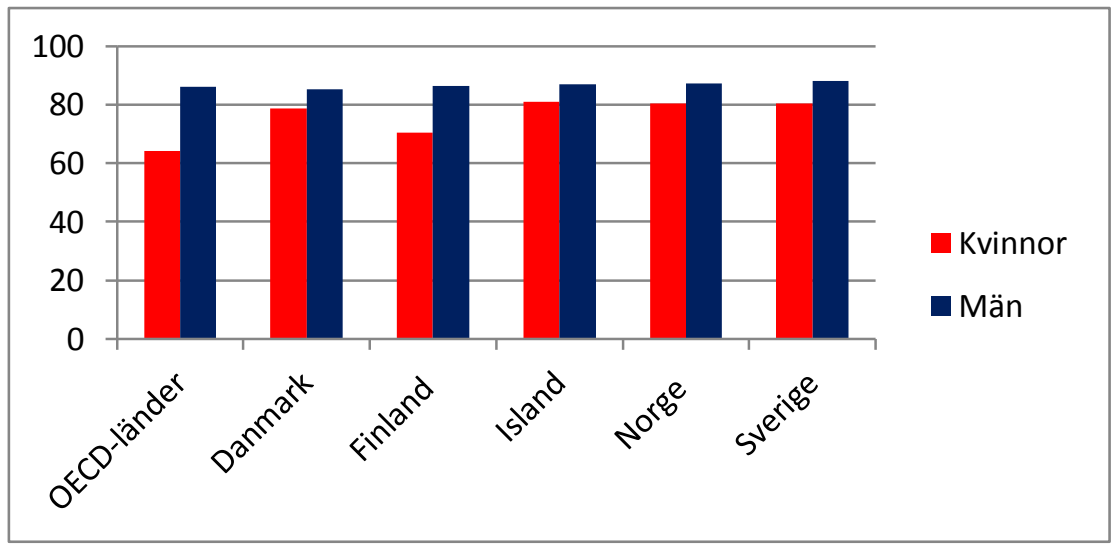

Anm.: Andelen sysselsatta i befolkningen. Procent.

Källa: AKU, OECD. 


\subsection{Arbetslöshet}

Figur 33 visar att Norge som i yngre åldersgrupper har lägst arbetslöshet, men till skillnad från i åldersgrupperna 15-19 och 20-24 år ligger Sverige och Finland relativt sett lägre än i de andra nordiska länderna. Till skillnad från åldersgruppen 25-29 är det i denna åldersgrupp entydigt (förutom Finland där det var lika) att kvinnor hade högre arbetslöshet än män i samtliga länder under 2011.

Figur 33: Arbetslöshet, totalt (a) och efter kön(b)

Figur 34a: Arbetslöshet, totalt, 30-34 år

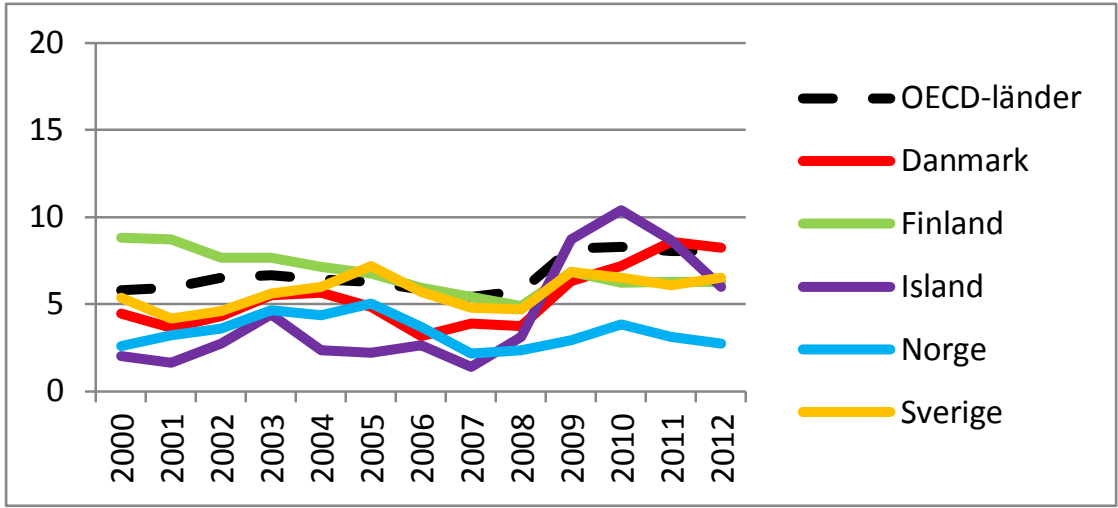

Anm.: Andelen arbetslösa av arbetskraften. Notera att skalan endast går till 20 procent. Källa: AKU, OECD. 
Figur 34b: Arbetslöshet för kvinnor och män, 30-34 år, 2012

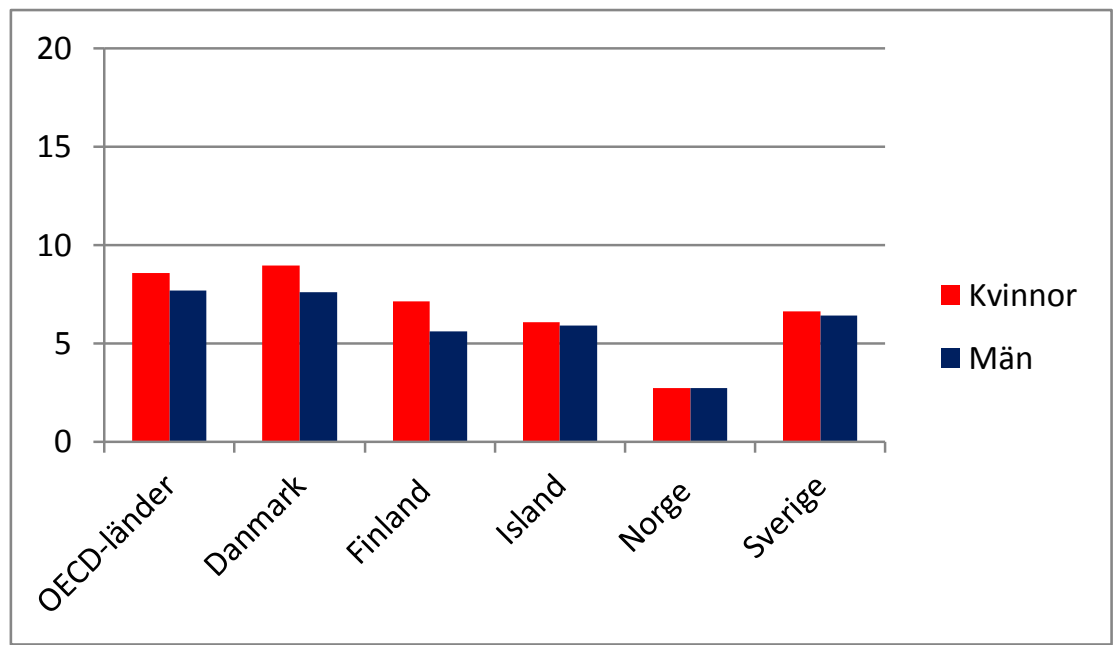

Anm.: Andelen arbetslösa av arbetskraften. Procent. Notera att skalan endast går till 20 procent. Källa: AKU, OECD. 


\section{Sammanfattning}

I denna rapport har situationen för unga i utbildning och på arbetsmarknaden i de olika nordiska länderna beskrivits med hjälp av olika statistiska mått. Ungdomar är nya på arbetsmarknaden och växlar oftare än vuxna mellan korta arbeten och korta perioder av arbetslöshet och studier och det återspeglas i statistiken. Ungdomar i Norden har hög studerandegrad relativt genomsnittet för OECD. Majoriteten av gymnasieungdomarna i nordens länder fullföljer också gymnasiet.

Sysselsättningsgraden är hög men uppvisar stora variationer mellan länderna, särskilt för de yngsta åldersgrupperna. Det beror delvis på hur gymnasieskolan är organiserad. I länder med förhållandevis hög sysselsättningsgrad sker den yrkesinriktade gymnasieutbildningen i större utsträckning i form av lärlingsutbildningar där eleverna som räknas som sysselsatta i statistiken eftersom de får lön. Skillnader mellan länderna kvarstår dock. Det finns unga som hamnar och varaktigt förblir utanför arbetsmarknaden. En nyligen publicerad studie uppskattar att runt tio procent (ca 300000 personer) av de unga i Norden är utsatta för risk för varaktigt utanförskap och att mellan två till fem procent (ca 70 till 150 000 personer) av de unga redan har hamnat i permanent utanförskap. ${ }^{20}$

Denna rapport ger inte svaret på vad skillnaderna mellan länderna beror på, men möjliga förklaringar är att de institutionella skillnaderna $\mathrm{i}$ lärlingssystemen ger olika god arbetsmarknadsanknytning, att länderna har olika flexibilitet i arbetsrätten, att olikheter i lägstalönenivåer spelar roll och att arbetskraftsefterfrågan skiljer sig mellan länderna.

Den nordiska ungdomsarbetslösheten är hög i jämförelse med arbetslösheten bland äldre. Under de senaste åren har den relativa arbetslösheten bland ungdomar (20-24 år) varit mellan ca två till tre gånger högre än

${ }^{20}$ Halvorsen (2011). 
arbetslösheten bland äldre (25-64 år). Andelen med korta arbetslöshetstider är högre för unga än för äldre, och långtidsarbetslösheten för unga är förhållandevis låg, särskilt i relation till genomsnittet för hela OECD. Långa tider i arbetslöshet minskar ungdomarnas jobbchanser. De som är arbetslösa länge förlorar sina färdigheter och kunskaper och de kan också bli mindre motiverade att hitta ett arbete med tiden som arbetslös. Unga har betydligt lägre långtidsarbetslöshet än äldre.

Sysselsättningsgraden för unga vuxna, de över 25 år, är hög. Det indikerar att de allra flesta etablerar sig på arbetsmarknaden. Skillnaden i sysselsättningsgrad mellan de nordiska länderna och OECD-länderna är större ju äldre åldersgrupper vi studerar. Det tycks som om etableringen alltså går bra i de nordiska länderna framförallt i jämförelse med OECD i genomsnitt. Även om ungas arbetskraftsutbud är viktigt att ta tillvara är arbetslösheten också ett uttryck för etableringsprocessen på arbetsmarknaden.

Vissa grupper har större svårigheter både under etableringsprocessen och senare i livet. Det rör sig framförallt om personer som inte fullföljer gymnasiet, som har funktionshinder som medför nedsatt arbetsförmåga eller som är utrikes födda och som kommit i en ålder efter skolstarten.

\section{Sysselsättningsutveckling för alla åldersgrupper 2012}

Här rekapituleras utvecklingen i sysselsättningsgrad och arbetslöshet för unga vuxna 15-34 år. Tidigare har detta redovisats i tidsserie för varje åldersgrupp separat.

Tvärsnitt för olika åldersgruppers sysselsättningsgrad år 2012 illustreras i Figur 34. De i åldersgruppen 15-19 år studerar i huvudsak. Det är stora variationer i sysselsättningsgrad mellan länderna som bland annat beror på hur de har organiserat sina gymnasieutbildningar. Som nämnts ovan så räknas lärlingar som sysselsatta i statistiken eftersom de får lön när de praktiserar på arbetsplatsen. Det är en faktor som höjer sysselsättningsgraden i de länder som har lärlingar (se Tabell 2). I åldersgruppen 20-24 år så är sysselsättningsgraden högre och variationerna mellan länderna mindre, men följer samma mönster med de länder som har hög andel lärlingar som också har hög sysselsättning mellan länderna. För unga mellan 25-29 år så har sysselsättningen ökat ytterligare, och det är inte längre så stora variationer mellan länderna. För unga vuxna mellan 30-34 år har skillnaden mellan länder minskat ytterligare. I de båda senare åldersgrupperna öka avståndet till OECD successivt. Rangordningen i 
sysselsättningsgrad som var mycket markant i de yngre åldersgrupperna är också annorlunda. I de yngre åldersgrupperna har Danmark och Norge, länder med lärlingssystem, alltid höga sysselsättningsgraderna. I de äldre åldersgrupperna är rangordningen mellan länderna annorlunda och för den äldsta åldersgruppen bl.a. så har Sverige den högsta sysselsättningsgraden. Så trots stora skillnader i sysselsättningsgrad bland de unga så uppnår de nordiska länderna höga, och mellan länderna lik, sysselsättningsgrad för unga vuxna.

Figur 34: Sysselsättningsgrad i olika åldersgrupper, År 2012

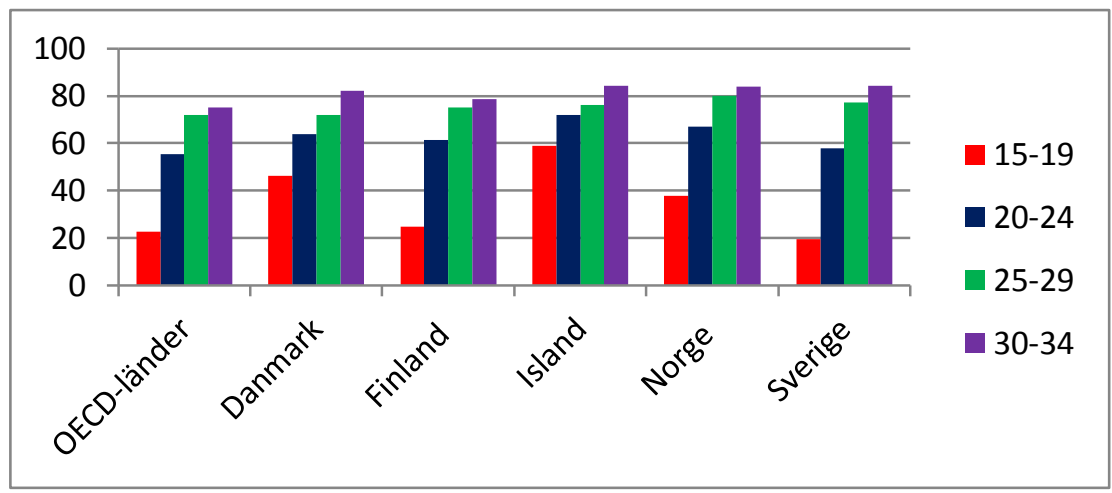

Anm.: Andelen sysselsatta i befolkningen i respektive ålderskategori. Procent.

Källa: AKU, OECD.

\section{Arbetslösheten för alla åldersgrupper 2012}

Motsvarande bild för arbetslöshet, dvs. för ett år och alla åldersgrupper i samma figur, ger en liknande slutsats. För de unga åldersgrupperna 15-19 år och 20-24 år är arbetslösheten i de länder som inte har lärlingssystem relativt sett mycket högre än i de länder som har lärlingssystem. Skillnaderna mellan länderna är också stora för de unga åldersgrupperna. I de äldre åldersgrupperna 25-29 år och 30-34 år så är variationerna mellan länderna små, och rangordningen i vilka länder som har höga arbetslöshetsnivåer annorlunda. Norge har genomgående låga arbetslöshetsnivåer. Det är viktigt att poängtera att Figur 35 visar aggregerade tal för arbetslöshet. Gruppen unga är mycket heterogen och det finns stora skillnader i arbetslöshet mellan olika grupper unga. 
Figur 35: Arbetslöshet i olika åldersgrupper, År 2012

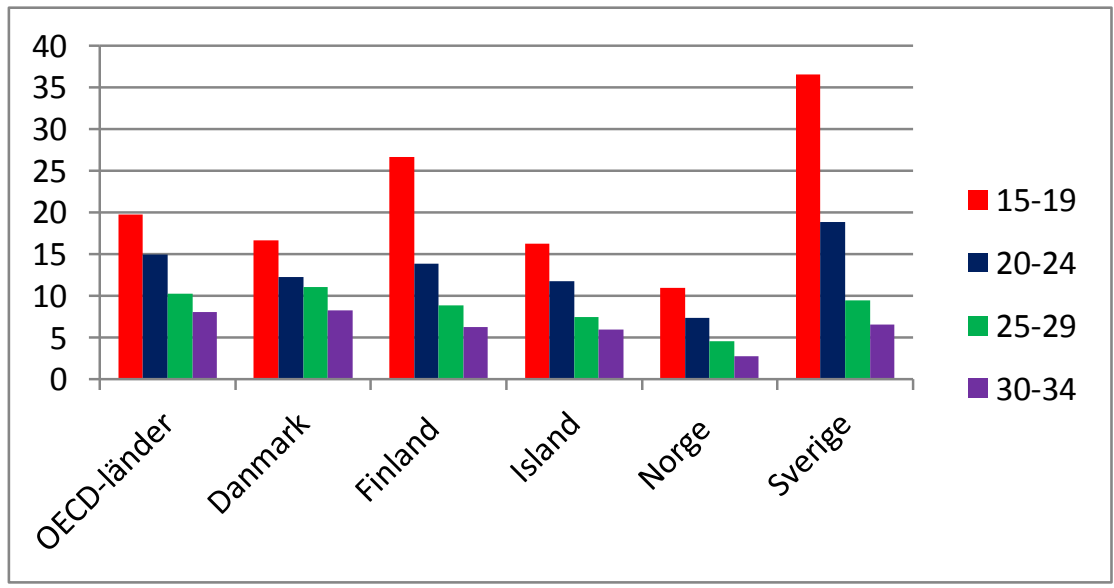

Anm.: Andelen arbetslösa av arbetskraften. Procent. Notera att skalan endast går till 40 procent. Källa: AKU, OECD. 


\section{Vidare läsning}

I den här rapporten har ungdomars situation inom utbildningssystemet och på arbetsmarknaden belysts ur olika synvinklar med olika statistiska källor. För att bättre förstå vad orsaker till de skillnaderna och likheterna som finns mellan de nordiska länderna refereras i detta avsnitt till litteratur där ungdomars situation i de nordiska länderna diskuteras vidare. Varken rapporten eller de referenser som nämnts nedan gör anspråk på att ge en heltäckande bild av ansatser och resultat varken i den nationella eller internationella forskningen. Referenserna nedan ges som exempel och möjlighet till fortsatt läsning.

Två rapporter som publicerats under de senare åren, och som ger en bred och övergripande bild av ungdomars situation i nordens länder, är Halvorsen (2012); Ungdomsarbeidsledighet i Norden - En studie av rettigheter og tiltak for unge arbeidssøkere Nordisk Socialstatistisk Komité (NOSOSKO) och Off to a Good Start? Jobs for Youth (OECD). Den politik som förs för att motverka ungdomsarbetslöshet i de olika nordiska länderna beskrivs bl.a. i Halvorsen (2012) och TemaNord 2010:570.

Varför fullföljer inte alla unga sin utbildning? Det finns såväl nordiska rapporter som studier av bl.a. OECD som påvisar vikten av ett antal bakgrundsfaktorer som ofta är liknande mellan länder. Särskilda referenser här är Olofsson och Wadensjö (2012); Bäckman m.fl. (2011); Myrskylä (2011); Markussen m.fl. (2008) och Jónasson och Bløndal (2002). OECD analyserar årligen fullföljandegraden i publikationen Education at a Glance.

Vissa grupper, förutom de som inte har fullföljt sin utbildning, har större svårigheter att etablera sig på arbetsmarknaden och har en högre risk för långtidsarbetslöshet. OECD beskriver och analyserar situationen för alla nordiska länder bl.a. i de tematiska publikationerna Sickness, Disability and Work; International Migration Outlook; Health at a Glance och Education at a Glance. 



\section{Referenser}

Berge, A. (2013). Hög lägstalön lönar sig. Lägstalönens betydelse för ett ekonomiskt och social hållbart samhälle. Handelsanställdas förbund.

Jónasson, J. T., och Bløndal, K. S. (2002). Ungt fólk og framhaldsskólinn. Reykjavík: Social Science Research Institute, University of Iceland and University Press.

Blondal, K. S. och Jónasson, J. T. (2003). Brottfall úr framhaldsskóla. Afstaða til skóla, stuðningur foreldra og bakgrunnur nemenda [School dropout. Attitudes to school, parental support and students' background]. In Friðrik H. Jónsson (Ed.), Rannsóknir í félagsvísindum IV. Reykjavík: University Press.

Bäckman O., Dahl E., Jakobsen V., Lorentzen T. och E. Österbacka (2011). Dropping out in Scandinavia. Social Exclusion and Labour Market Attachment among Upper Secondary School Dropouts in Denmark, Finland, Norway and Sweden. Arbetsrapport Nr 2011:8, Institutet for Framtidsstudier.

Halvorsen, B. (2012). Unge på kanten - Om inkludering av utsatte ungdommer. Nord 2012:005, Nordiska ministerrådet, Köpenhamn 2012.

International human development index (2012), UNESCO Institute for Statistics.

Nordiska länders insatser mot ungdomsarbetslöshet - kartläggning och analys, Nordiska Ministerrådet, 2010:570 Rambøll Management Consulting AB.

Markussen, E. M. W., Frøseth, B., Lødding och N. Sandberg (2008). Bortvalg og kompetanse. Rapport 13. NIFU STEP, Oslo.

Myrskylä P. (2011). "Unga utanför". Arbets- och näringsministeriets publikationer 12/2011, Helsingfors.

Mörk, E. (2011). "Från försörjningsstöd till arbete - Hur kan vägen underlättas?", i Välfärdsstaten i arbete - Inkomsttrygghet och omfördelning med incitament till arbete, SOU 2011:2, Fritzes, Stockholm.

Nordström Skans, 0. (2008). How does the age structure affect regional productivity? Applied Economics Letters 15, 787-790.

Nordström Skans, 0.(2009). "Varför är den svenska ungdomsarbetslösheten så hög?" Studier i finanspolitik 2009/6, Finanspolitiska rådet, Stockholm.

Ungdomsarbeidsledighet i Norden - En studie av rettigheter og tiltak for unge arbeidssøkere. Nordisk Socialstatistisk Komité (NOSOSKO) nr. 47:2011, Köpenhamn.

OECD (2010). Off to a Good Start? Jobs for Youth. OECD Publishing.

OECD (2012). Health at a Glance, OECD Publishing.

OECD (2010). Sickness, Disability and Work. Breaking the barriers. A Synthesis of Findings across OECD Countries. OECD Publishing.

OECD (2010). Economic Survey of Sweden. OECD Publishing.

OECD (2012). Education at a Glance 2012. OECD Indicators. OECD Publishing. 
OECD (2009-2011). Employment Outlook 2009-2011.

Olofsson, J. och Wadensjö, E. (2007). Ungdomars villkor i de nordiska länderna lika men ändå olika. Stockholm: FAS.

Olofsson J. och Wadensjö E. (2012)."Youth, education and labour market in the Nordic countries - similar but not the same”, i rapportserie (totalt 12 länderrapporter), Friedrich Ebert Stiftung i Berlin.

Temagruppen unga i arbetslivet (2011). Unga som varken arbetar eller studerar. Hur många är de och vad gör de? Ungdomsstyrelsen, Stockholm.

Skedinger, P. (2007). Minimilöners effekter på sysselsättning och löner - en översikt. Arbetsmarknad \& Arbetsliv, årg 13, nr 2, sommaren 2007.

Skedinger, P. (2008), Effekter av anställningsskydd - vad säger forskningen, SNS förlag, Stockholm.

Statistiska Centralbyrån (2013). Ungdomsarbetslöshet - jämförbarhet i statistiken mellan ett antal europeiska länder, 2013:1.

Statistiska Centralbyrån (2009). Tema - Ungdomsarbetslöshet. Statistiska meddelande AM 11 SM 0902.

TemaNord 2010: 570 Nordiska länders insatser mot ungdomsarbetslöshet - kartläggning och analys. Rambøll Management Consulting AB. 


\section{Summary}

In this report, the situation regarding young people in education and employment is described, using various statistical measures. Young people are new to the labour market and, more often than adults, alternate between short periods of working, unemployment, and education, and this is shown in the statistics. Young people in the Nordic countries have a higher level of education than the average in the OECD countries, and the majority of upper secondary students complete their programmes.

The employment rate is high, but the rate varies greatly between countries, particularly for the youngest year groups. This is partly due to how upper secondary education is organised. In countries with a relatively high employment rate, vocational upper secondary education often involves apprenticeship programmes, and students are regarded as employed in the statistics because they receive salaries. However, differences between the countries remain. There are young people who remain outside the labour market for very long periods. In a recently published study, an estimated ten percent (approximately 300,000 people) of young people in the Nordic region are at risk of long-term exclusion, and between two and five percent (approximately 70 to 150,000 people) of young people are already permanently excluded. ${ }^{21}$

This report does not offer an explanation for the differences between countries, but one possible reason is that institutional differences in apprenticeship systems produce differences in how well they are linked to the labour markets. Other possible explanations are that countries have varying degrees of flexibility when it comes to employment law, that differences in minimum wage levels are important, and that the demand for labour varies between countries.

${ }^{21}$ Halvorsen (2011). 
The unemployment rate of young people in the Nordic countries is higher than that of older people. In recent years, relative unemployment among young people (20-24 years) has been approximately two to three times higher than that of older people (25-64 years). The proportion of young people experiencing short periods of unemployment is higher than that of older people, but long-term unemployment of young people is relatively low, particularly in relation to the average for all OECD countries. Long periods of unemployment make it harder for young people to find jobs. People who are unemployed for long periods lose their skills and expertise, and they may become less motivated to find a job the longer they are unemployed. Long-term unemployment rates for young people are considerably lower than for older people.

For young adults (over 25 years), the employment rate is high, indicating that most people do become established on the labour market. The difference in employment rate between Nordic countries and OECD countries is greater for the older year groups considered in this study. People seem to become well established on the labour market in the Nordic countries, particularly in comparison with the average for the OECD countries. Even if it is important to utilise the labour supply of young people, unemployment also reflects the process of how well people become established on the labour market.

Certain groups have greater difficulties, both during the establishment process and later in life. This applies primarily to people who do not complete upper secondary education, those who have disabilities that reduce their capacity to work, and those who were born in other countries and have not gone through the entire school system.

\section{Employment trends for all age groups, 2012}

In this section, employment and unemployment trends relating to young adults (15-34 years) are presented. Previously, this has been shown in time series for each year group separately.

Average figures for the level of employment in various age groups in 2012 are shown in Figur 34. People in the 15-19 age group are mainly engaged in education. The level of employment varies greatly between countries, partly because of the way upper secondary education is organised. Apprentices are included as employed in the statistics because they receive a salary when they are on work placement. This raises the level of 
employment in countries with apprenticeship systems (see Tabell 2). In the 20-24 age group, the level of employment is higher, and variations between countries smaller, but the trend is the same as in countries with a high proportion of apprentices. In the 25-29 age group, the employment rate has increased further, and variations between countries are decreasing. In the 30-34 age group, the differences between countries have decreased even further. In both the 25-29 and 30-34 age groups, the difference between employment rate in the Nordic countries and OECD countries has gradually increased. Employment rate rankings, which showed a very distinct pattern in the younger age groups, have also changed. In the younger year groups, Denmark and Norway, countries with apprenticeship systems, have consistently high employment rates. In the older age groups, the ranking between the countries changes; in the oldest age group, for example, Sweden has the highest employment rate. Consequently, in spite of major differences in employment rate among young people, employment rates for young adults are consistently high in the Nordic countries.

Figure 36. Employment rate in various age groups, 2012

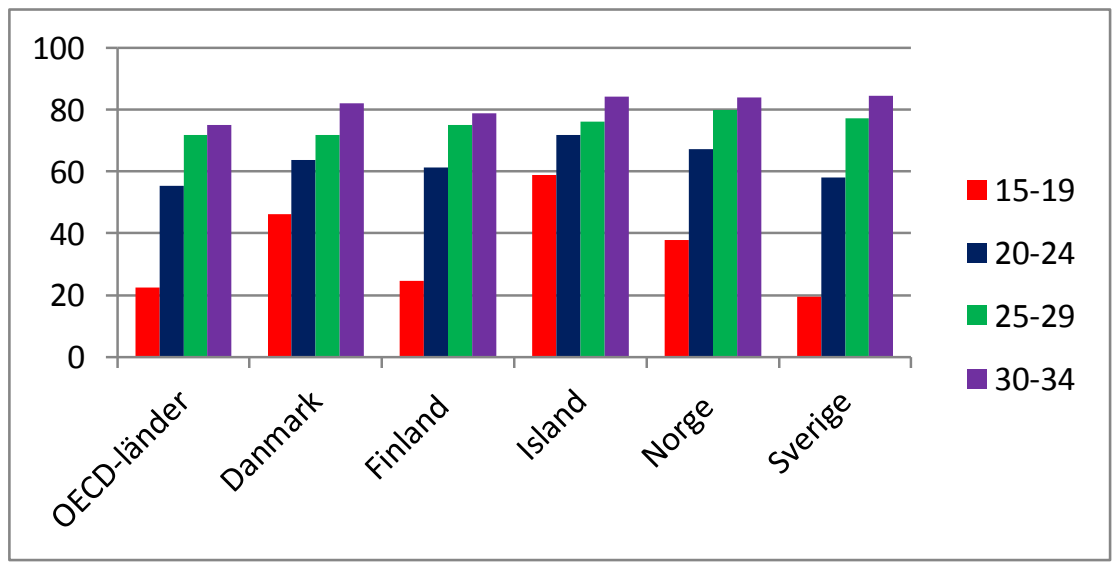

Employment rate for the population in each age group (figures in percent).

Source: AKU, OECD. 


\section{Unemployment figures for all age groups, 2012}

The corresponding pattern for unemployment for all age groups in 2012, shown in Figure 36, leads to a similar conclusion. For the younger age groups, 15-19 and 20-24, unemployment in the countries that do not have apprenticeship systems, is relatively high compared to the countries that do have such systems. Differences between countries are also great for the younger age groups. In the older age groups, 25-29 and 30-34, variations between the countries become smaller, and ranking of the countries in terms of unemployment rate changes. Norway has consistently low levels of unemployment. It is important to emphasise that Figur 35 shows aggregated figures for unemployment. The young people's group is very heterogeneous, and unemployment rates vary greatly between different groups of young people.

Figure 37. Unemployment rate in various age groups, 2012

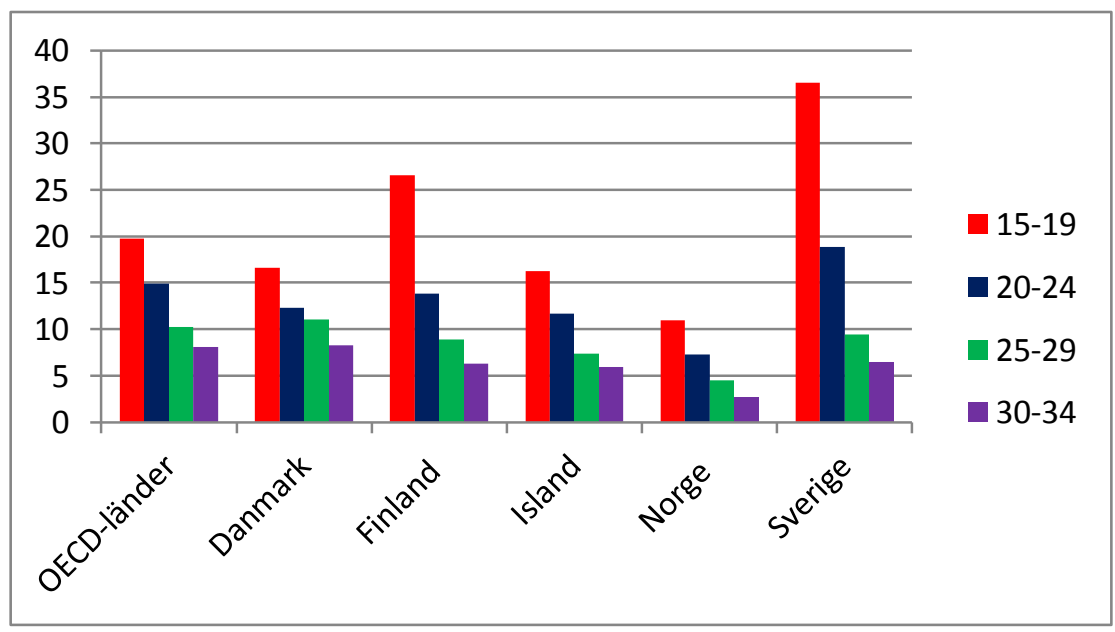

Proportion of the labour force that is unemployed (figures in percent). Note that the scale only goes up to 40 percent.

Source: AKU, OECD. 


\section{Bilaga 1: \\ Arbetskraftsundersökningarna (AKU)}

Arbetskraftsundersökningarna (AKU) beskriver utvecklingen på arbetsmarknaden för ett lands befolkning. Den statistikmyndighet i respektive land som har hand om AKU ställer frågor till ett urval av personer från befolkningen som är mellan 15-74 år beträffande deras arbetssituation vid en viss tidpunkt, kallat referensveckan. ${ }^{22}$ För att räknas som sysselsatt krävs att respondenten har arbetat minst en timme under referensveckan eller varit tillfälligt frånvarande från arbetet pga. sjukdom, semester, tjänstledighet eller dylikt.

De intervjuade klassificeras i någon av kategorierna i arbetskraften (sysselsatta eller arbetslösa, d.v.s. söker arbete eller väntar på att tillträda ett arbete som ska starta inom tre månader) eller att de inte deltar i arbetskraften. Klassificeringen i olika grupper beror på om urvalspersonen har utfört arbete eller om urvalspersonen har sökt arbete. Eftersom definitionerna av arbetslöshet och sysselsättning inte beror på om en person är studerande eller inte, kan en studerande klassificeras som såväl sysselsatt, arbetslös eller utanför arbetskraften. Trädet som beskrivs i figur 22 är anpassat för att ge en bild av ungdomsarbetslösheten, där fokus förutom ligger på studerande på de ordinarie kategorierna som beskrivs ovan. ${ }^{23}$

\footnotetext{
22 På Island är urvalet 16-74 år. Detta får effekt på skattningarna av antalet arbetslösa och det relativa arbetslöshetstalet, speciellt för redovisningsgruppen "Ungdomar 15-24 år".

${ }^{23}$ AKU reviderades 2005 med syftet att harmonisera data med EU:s standard för insamling av arbetslöshetsdata. I nuvarande definition är en person arbetslös om hen är utan arbete i referensveckan och kunde arbeta inom två veckor och aktivt söker arbete (eller väntar på ett arbete som börjar inom tre månader). Tidigare (innan april 2005) krävdes att respondenten ville arbeta under referensveckan samt att de räknades som arbetslösa enbart om de väntade på ett arbete som skulle börja inom en månad. Föränd-
} 


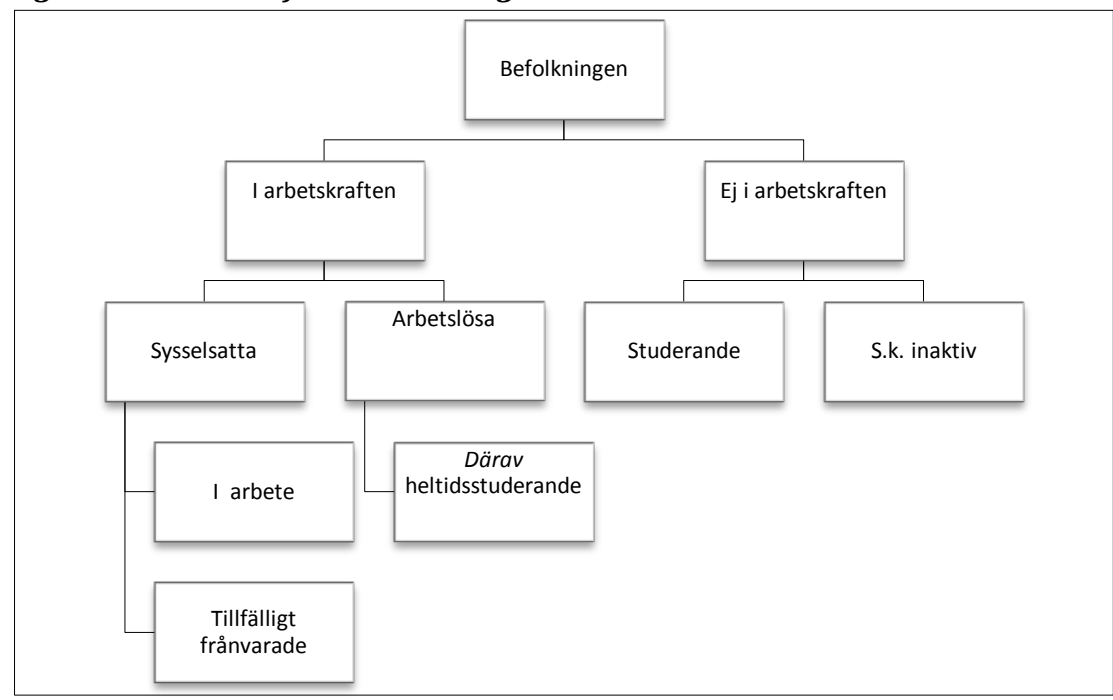

\section{Ord och begrepp i statistiken}

- Arbetskraftsstatus - Anger om individen är en del av arbetskraften eller inte. De individer som är sysselsatta eller arbetslösa tillhör arbetskraften och övriga är därmed utanför arbetskraften.

- Sysselsatt - En person som uppfyller något av nedanstående klassificeras som sysselsatt.

- Var i arbete under referensveckan, dvs. utförde något arbete (minst en timme). Arbetet kan vara som avlönad arbetstagare, egen företagare (inklusive fri yrkesutövare) eller oavlönad medhjälpare i företag tillhörande make/maka eller annan medlem av samma hushåll.

○ Inte utförde något arbete enligt ovan, men hade en anställning, ett arbete som medhjälpande hushållsmedlem eller egen företagare (inklusive fri yrkesutövare) och var tillfälligt frånvarande hela referensveckan. Frånvaron räknas oavsett om den varit betald eller inte. Orsak till frånvaron kan vara sjukdom, föräldraledighet, semester, tjänstledighet, (t.ex. för vård av barn eller studier), 
värnpliktstjänstgöring, arbetskonflikt eller ledighet av annan anledning.

○ Deltog i ett arbetsmarknadspolitiskt program där en lön utbetalas från arbetsgivaren (Samhall, anställning med lönebidrag, instegsjobb m.m.), alternativt får aktivitetsstöd för start av näringsverksamhet.

○ Deltog en lärlingsutbildning där lön u utbetalas från arbetsgivaren.

- Arbetslös - En person som uppfyller något av nedanstående klassificeras som arbetslös.

- Var utan arbete under referensveckan men sökt arbete under de senaste fyra veckorna (referensveckan och tre veckor bakåt) och kunde arbeta referensveckan eller börja inom 14 dagar från referensveckans slut. Även en heltidsstuderande som uppfyller dessa villkor klassificeras som arbetslös.

- Var utan arbete under referensveckan men fătt ett arbete som börjar inom tre månader, förutsatt att han/hon skulle ha kunnat arbeta referensveckan eller börja inom 14 dagar från referensveckans slut.

- Ej i arbetskraften - En person som inte uppfyller villkoren för att klassificeras som sysselsatt eller arbetslös är utanför arbetskraften och orsaken till detta kan vara något av nedanstående.

- Personen är exempelvis studerande (se dock ovan under arbetslös om heltidsstuderande som sökt och kan ta arbete),

- eller är pensionär, hemarbetande, värnpliktig, övrigt eller långvarigt sjuk. Även de som velat och kunnat ta arbete under referensveckan men inte sökt något arbete, s.k. latent arbetssökande tillhör denna grupp. 



\section{Bilaga 2: \\ Jämförbarhet i statistiken mellan de nordiska länderna}

Statistiska centralbyrån (SCB) har undersökt hur jämförbar arbetskraftsundersökningarna (AKU) för unga är mellan de nordiska länderna..24 De finner att AKU är väl harmoniserad och följer ILO:s definitioner och regelverk. SCB:s sammantagna slutsats är att jämförbarheten i statistiken över ungdomsarbetslöshet är mycket god. Den genomgång SCB gjort, med stöd av statistikbyråerna i de berörda länderna och Eurostat, visar att de brister som finns är av marginell betydelse och att de inte påverkar den övergripande bilden av arbetsmarknaden. För specifika undergrupper, såsom utlandsfödda, kan dock jämförbarheten vara begränsad.

Skillnaderna i arbetslöshetsnivå mellan länderna måste således förklaras av andra faktorer än jämförbarhetsbrister i statistiken. Institutionella faktorer, framförallt utbildningssystemens utformning, kan till stor del förklara att ungdomsarbetslösheten skiljer sig åt mellan länderna. Omfattande lärlingssystem, där lärlingarna får ersättning, har stor effekt på ungdomsarbetslöshetens nivå. Även utbetalning av studiemedel för sommarmånaderna påverkar nivån. 

12. Bilaga 3:

Grund- och gymnasieskolans organisering i de nordiska länderna 
Tabell 7: Grund- och gymnasieskolans organisering i de nordiska länderna

\begin{tabular}{|c|c|c|c|c|c|}
\hline & Danmark & Finland & Island & Norge & Sverige \\
\hline $\begin{array}{l}\text { Förväntat totalt } \\
\text { antal år i utbild- } \\
\text { ning }\end{array}$ & 16,8 år & 16,9 år & 18,3 år & 17,5 år & 16,0 år \\
\hline \multicolumn{6}{|l|}{ Grundskolenivå } \\
\hline Styrning via lag & $\begin{array}{l}\text { Statlig lagstiftning med instrukt- } \\
\text { ioner för utbildningens mål o } \\
\text { standard }\end{array}$ & $\begin{array}{l}\text { Statlig lagstiftning med } \\
\text { instruktioner för utbild- } \\
\text { ningens mål o standard }\end{array}$ & $\begin{array}{l}\text { Statlig lagstiftning med } \\
\text { instruktioner för utbild- } \\
\text { ningens mål o standard }\end{array}$ & $\begin{array}{l}\text { Statlig lagstiftning med } \\
\text { instruktioner för utbildning- } \\
\text { ens mål o standard }\end{array}$ & $\begin{array}{l}\text { Statlig lagstiftning med } \\
\text { instruktioner för utbild- } \\
\text { ningens mål o standard }\end{array}$ \\
\hline $\begin{array}{l}\text { Styrning prak- } \\
\text { tiskt utförande }\end{array}$ & Kommunal och regional & Kommunal och regional & Kommunal och regional & Kommunal och regional & Kommunal och regional \\
\hline $\begin{array}{l}\text { Privata utbild- } \\
\text { nings-anordnare }\end{array}$ & $\begin{array}{l}\text { Föreningsanknuten undervisning } \\
\text { utgör } 10 \text { procent }\end{array}$ & Försumbart & Försumbart & Försumbart & $\begin{array}{l}\text { Friskolor utgör } \mathrm{x} \text { procent } \\
\text { på grundskolenivå }\end{array}$ \\
\hline Avgifter & $\begin{array}{l}\text { Inga avgifter tillåtna på grund- } \\
\text { skolenivå. }\end{array}$ & $\begin{array}{l}\text { Inga avgifter tillåtna på } \\
\text { grundskolenivå. }\end{array}$ & $\begin{array}{l}\text { Inga avgifter tillåtna på } \\
\text { grundskolenivå. }\end{array}$ & $\begin{array}{l}\text { Inga avgifter tillåtna på } \\
\text { grundskolenivå. }\end{array}$ & $\begin{array}{l}\text { Inga avgifter tillåtna på } \\
\text { grundskolenivå. }\end{array}$ \\
\hline Tid i grundskolan & $\begin{array}{l}9 \text { (+1) år. Möjlighet till ytterligare } \\
\text { år om ej behörig eller behov } \\
\text { finns. }\end{array}$ & $\begin{array}{l}9(+1) \text { år. Möjlighet till } \\
\text { ytterligare år om ej } \\
\text { behörig eller behov } \\
\text { finns. }\end{array}$ & 10 år & 10 år & 9 år \\
\hline $\begin{array}{l}\text { Ålder när } \\
\text { grundskolan } \\
\text { slutar }\end{array}$ & 16 (17) år & 16 (17) år & 16 år & $16 \mathrm{år}$ & 16 år \\
\hline \multicolumn{6}{|l|}{ Gymnasienivå } \\
\hline Rättighet & $\begin{array}{l}\text { Gymnasieskolan är en rättighet } \\
\text { om behörighetskraven är upp- } \\
\text { fyllda. }\end{array}$ & $\begin{array}{l}\text { Gymnasieskolan är en } \\
\text { rättighet om behörig- } \\
\text { hetskraven är uppfyllda. }\end{array}$ & $\begin{array}{l}\text { Gymnasieskolan är en } \\
\text { rättighet om behörighets- } \\
\text { kraven är uppfyllda. }\end{array}$ & $\begin{array}{l}\text { Gymnasieskolan är en } \\
\text { rättighet om behörighets- } \\
\text { kraven är uppfyllda. }\end{array}$ & $\begin{array}{l}\text { Gymnasieskolan är en } \\
\text { rättighet om behörighets- } \\
\text { kraven är uppfyllda. }\end{array}$ \\
\hline
\end{tabular}


Utbildningens

organisering

Avgifter

Studiebidrag

Efter 18 år generöst system

kombinerat bidrag och studielån.

gift men att ta ut avgift för

studiematerial.

terminsavgift men att ta

ut avgift för studie-

material.

Generellt studiebidrag

och möjlighet att söka

studielån.

Kan senast börja Ingen övre åldersgräns personer över 16. Dock

möjligheter till studielån

för yrkesgymnasial utbild-

ning

Fyra skolformer:

Läroverk som avslutas med

studentprov som ger

Särskilda yrkeskolor med

utbildningar som resulterar

yrkes-certifikat

Integrerade gymnasiesko-

lor som erbjuder både

kademiskt inriktade

utbildningsprogram och

inriktade skolor som

erbjuder utbildningar mot

snävt avgränsade yrkesom-

råden.

Tillåtet att ta ut terminsavTift. Tillåtet att ta ut avgift för studiematerial. gymnasieskolan.
Aldre personer utan fullbordad utbildning rätt att söka

Integrerad gymnasieut-

bildning (samma för

studie- och yrkesförberedande). Uppdelat på:

Allmänteoretiska skolor som förbereder för akademiska studier

2a) Skolförlagd yrkesutbildning (kan ge grundläggande behörighet till

vidare studier).

2b)Lärlingsutbildning (kan ge grundläggande behö-

righet till vidare studier)

Inte tillåtet att ta ut terminsavgift men att ta ut avgift för studiematerial.

Behovsprövade bidrag och lån.

bidrag motsvarande

barnbidraget. Ej studielån.

Kan max vara 20 år för att börja gymnasieskolan.

vift om skolan ska f. stadsbidrag. Inte tillåtet att ta ut avgifter för studiematerial.

\section{Eftergymnasial nivå}

Hur många

12 månader

månader om

året kan man få

studielån?
9 månader 



\section{Bilaga 4: \\ Lagstiftning kring tidsbegränsade anställningar}

"Den nordiska arbetsmarknadsmodellen" används ofta som en sammanfattande benämning på en uppsättning arbetsmarknadsrelaterade institutioner i norden hög facklig organiseringsgrad och kollektivavtalstäckning, generös arbetslöshetsersättning och frånvaro av direkt statlig inblandning i lönebildningen. Arbetsmarknaden är reglerad genom kollektivavtal i de nordiska länderna. Det innebär att löner och anställningsvillkor bestäms genom kollektiva överenskommelser mellan fackförbund och arbetsgivarorganisationer. I de nordiska länderna, med undantag av Norge, är den fackliga organisationsgraden hög. I Sverige är ca 80 procent av löntagarna medlemmar i fackliga organisationer medan ca 50 procent av löntagarna i Norge är organiserade. En förklaring till den lägre organisationsgraden i Norge är att arbetslöshetsförsäkringen är obligatorisk i Norge. I Danmark, Finland och Sverige är arbetslöshetsförsäkringen länkad till fackföreningar. Det är dock möjligt att vara försäkrad mot arbetslöshet utan att vara medlem i en fackförening.

I flera av nordiska länder finns det också ett starkt lagstadgat anställningsskydd (Danmark och Island har inte relativt sett starka anställningsskydd). Ett starkt anställningsskydd ökar arbetsgivarens kostnader för uppsägningar, men ökar också kostnaderna för nyanställningar eftersom arbetsgivare tar hänsyn till framtida uppsägningskostnader redan vid anställningsbeslutet. Detta leder till att både uppsägningar och nyanställningar minskar, vilket medför en tvetydig effekt på sysselsättningens nivå men dämpar dess svängningar över konjunkturcykeln.

Det finns tydliga skillnader mellan de nordiska länderna i fråga om styrka i anställningsskydd. I Sverige är regleringarna striktare än genomsnittet när det gäller reguljära anställningar och kollektiva uppsägningar, men något liberalare än genomsnittet i fråga om tidsbegränsade anställ- 
ningar. Sverige och Island är de länder som uppvisar störst skillnad i styrka i anställningsskyddet mellan tidsbegränsade och fasta anställningar. Danmark och Island är de länder som har det lägsta totala anställningsskyddet av de nordiska länderna.

Figur 39: Styrka i anställningsskydd 2012

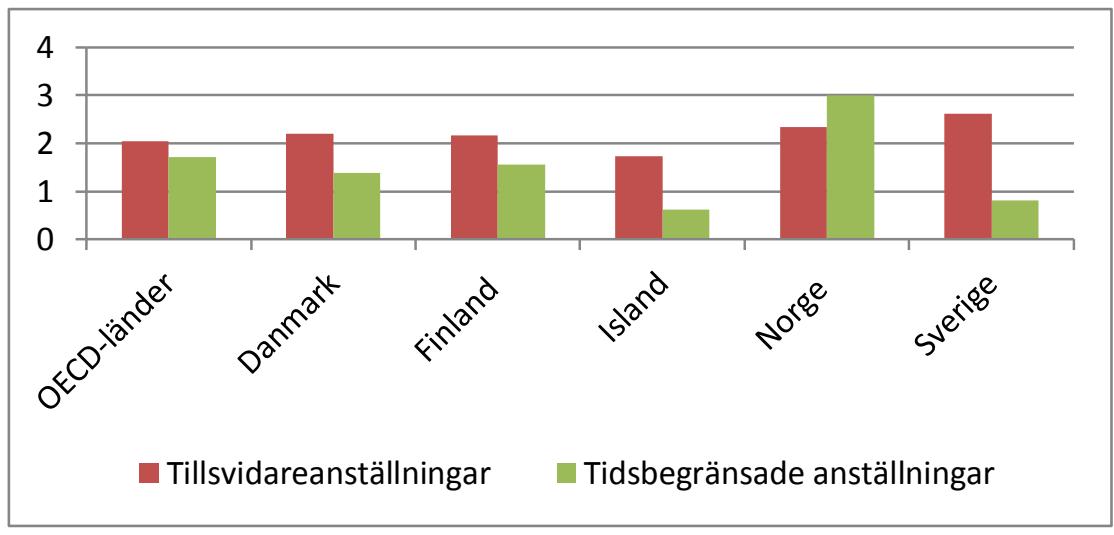

Index i Figur 39 är ett sammanvägt mått på styrkan i anställningsskyddet. Detta är det mest omfattande indexet avseende lagstiftningens olika beståndsdelar och har konstruerats av OECD. Index beaktar regelverket inom samtliga de huvudområden som är viktiga för anställningsskydd, nämligen tillsvidareanställningar, tidsbegränsade anställningar och kollektiva uppsägningar. Indexet har en heltalsskala mellan 0 och 6 , där den högsta siffran representerar den mest strikta lagstiftningen. OECD har uppdaterat och utökat sitt index flera gånger sedan 1990-talet, både vad avser komponenterna i indexet och antalet länder som ingår. Det är svårt att fånga lagstiftningens alla aspekter i indexet bl.a. pga. komplexiteten i lagstiftningen. Men även skillnader i rättstillämpning kan försvåra möjligheterna till en rättvisande bild 
Nordiska ministerrådet

Ved Stranden 18

DK-1061 København K

www.norden.org

\section{Unga i arbete i Norden}

Under det svenska ordförandeskapet i Nordiska ministerrådet år 2013 har Sverige fördjupat det nordiska regeringssamarbetet kring några av de stora framtidsutmaningar som är gemensamma för Norden. En viktig framtidsutmaning är att få fler unga i arbete. Ungdomsarbetslösheten är en utmaning för samtliga nordiska länder, men erfarenheterna och åtgärderna skiljer sig åt.

Under ordförandeskapsåret har det därför skett ett brett kunskapsutbyte mellan de nordiska länderna om hur ungdomars inträde i arbetslivet kan underlättas. En del i kunskapsutbytet om ungas arbetsmarknadssituation skedde under ett nordiskt arbetsmarknadsmöte den 16 maj 2013 i Stockholm. Vid mötet utbytte bl.a. de nordiska stats- och arbetsmarknadsministrarna erfarenheter och diskuterade ungdomars situation på arbetsmarknaden. Inför erfarenhetsutbytet på mötet togs ett statistiskt jämförande översiktsunderlag över ungas situation på arbetsmarkanden $\mathrm{i}$ de nordiska länderna fram. Denna rapport bygger på det bakgrundsmaterialet och $\mathrm{i}$ rapporten redovisas figurerna och tabellerna. 